\title{
REE and trace element patterns from organic-rich rocks of the Ediacaran- Cambrian transitional interval
}

\author{
Qingjun Guo ${ }^{\mathrm{a}, *}$, Yinan Deng ${ }^{\mathrm{a}, \mathrm{b}}$, Dorothee Hippler ${ }^{\mathrm{c}}$, Gerhard Franz ${ }^{\mathrm{c}}$, Junming Zhang ${ }^{\mathrm{d}}$ \\ a Institute of Geographic Science and Natural Resources Research, Chinese Academy of Sciences, Beijing 100101, China \\ b Key Laboratory of Marine Mineral Resources, Guangzhou Marine Geological Survey, Ministry of Land and Resources, Guangzhou 510075, China \\ c Institute of Applied Geosciences, Technical University Berlin, Ackerstr. 76, 13355 Berlin, Germany \\ ${ }^{\mathrm{d}}$ Nanjing Institute of Geology and Palaeontology, Chinese Academy of Sciences, Nanjing 210008, China
}

\section{A R T I C L E I N F O}

\section{Article history:}

Received 10 August 2015

Received in revised form 29 February 2016

Accepted 17 March 2016

Available online 24 May 2016

Handling Editor: R.D. Nance

\section{Keywords:}

Ediacaran-Cambrian interval

Trace elements and REE

Two oxidation events

The Yangtze Platform, South China

\begin{abstract}
A B S T R A C T
It has been established that important changes in the marine environment and the biosphere occurred during the Cambrian. However, the relationships between the so-called "Cambrian Explosion" and the concomitant environmental changes are not yet fully understood. This study presents new geochemical data from the black shale successions from different facies belts of the Yangtze Platform in South China. Variations in the concentrations of REE and trace elements (varying $\mathrm{Ce} / \mathrm{Ce} * \mathrm{Th} / \mathrm{U}, \mathrm{V} / \mathrm{Sc}$, and $\mathrm{V} / \mathrm{Cr}$ ratios) in kerogen as well as in bulk rocks from different depositional environments along a transect from platform to basin indicate two oxidation events, which led to the oxygenation of the water column in shallow-marine environments and euxinic conditions (weak correlation between TOC, V, U, and Mo) in the deeper sea. During the first oxidation event in the late Terreneuvian, anoxic conditions in bottom waters rapidly changed to euxinic conditions. Subsequently, the second oxidation event during the early Epoch 2 of the Cambrian led to oxic-suboxic conditions in deeper seawater. (c) 2016 International Association for Gondwana Research. Published by Elsevier B.V. All rights reserved.
\end{abstract}

\section{Introduction}

The Ediacaran to Early Cambrian interval is among the most pivotal periods in geological history (e.g., Zhu et al., 2007; Komiya et al., 2008; Maloof et al., 2010), experiencing, amongst other events, the rise of animals coincident with major changes in the marine environment and ocean chemistry (e.g., Knoll and Carroll, 1999; Marshall 2006; Zhu et al., 2007; Shu, 2008). Numerous studies have centered on the fossil record, the sedimentology, and the geochemistry of this period (Richard, 1998; Wu et al., 1999a, b; Yang et al., 2003; Yang et al., 2004; Xiao et al., 2005; Tribovillard et al., 2006; Goldberg et al., 2007; Jiang et al., 2007; Lehmann et al., 2007; Schröder and Grotzinger, 2007; Zhu et al., 2007; Guo et al., 2007a, b; Ishikawa et al., 2008; Sawaki et al., 2008; Wille et al., 2008; Guo et al., 2013; Ishikawaa et al., 2013; Pi et al., 2013; Xu et al., 2013; Feng et al., 2014; Och et al., 2015; Wang et al., 2015). Anoxic to euxinic conditions have been proposed for the early Cambrian based on the widespread deposition of black shales, the enrichment of certain redox-sensitive trace metals such as Mo, Ni, and PGE (Pt-group elements), and the prominent negative shifts in the isotopic evolution of $C$ (lower $\delta^{13} \mathrm{C}_{\text {Corg }}$ values, e.g., Guo

\footnotetext{
* Corresponding author. Tel.: +8610 64889455; fax: +861064889455.

E-mail address: guoqj@igsnrr.ac.cn (Q. Guo).
}

et al., 2007a, 2007b; Guo et al., 2013) and S (the minimum $\delta^{34}$ S values; e.g., Goldberg et al., 2007; Guo et al., 2007a; Feng et al., 2014; Och et al., 2015). In contrast, oxygenation of near-bottom waters has been proposed because of the occurrence of the various benthic organisms, such as sponges and arthropods (e.g., Xiao et al., 2005; Zhao et al., 2014). But the mechanisms of the changes in environment are not yet fully understood, and the ambient paleoenvironmental conditions prevailing during the deposition of these sedimentary successions are still a matter of debate.

Previous studies have applied trace element data to solve environmental conditions. However, such studies have also uncovered effects that likely mask the primary redox signatures. Bulk rock analyses may be influenced by detrital material, hence, do not necessarily reflect the authigenic nature of components from the marine environment (Pi et al., 2013). In addition, hydrothermal inputs of $\mathrm{Ni}, \mathrm{U}, \mathrm{Cr}$, and $\mathrm{V}$ can distort the original trace element values (such as: Th/U, V/SC, and $\mathrm{V} / \mathrm{Cr}$ ), which prevents conclusions being made on the redox conditions in the paleo-ocean (Pan et al., 2004). However, indigenous insoluble organic matter (or kerogen), mainly derived from algal material, plankton, and achritarchs from the euphotic zone of the upper water column (Wu et al., 1999a, 1999b), could represent suitable alternative material. Investigating the geochemical fingerprint of unaltered kerogen could therefore be a promising approach for reconstructing upper water column conditions. Rare earth elements (REE) are known to be organophile, 


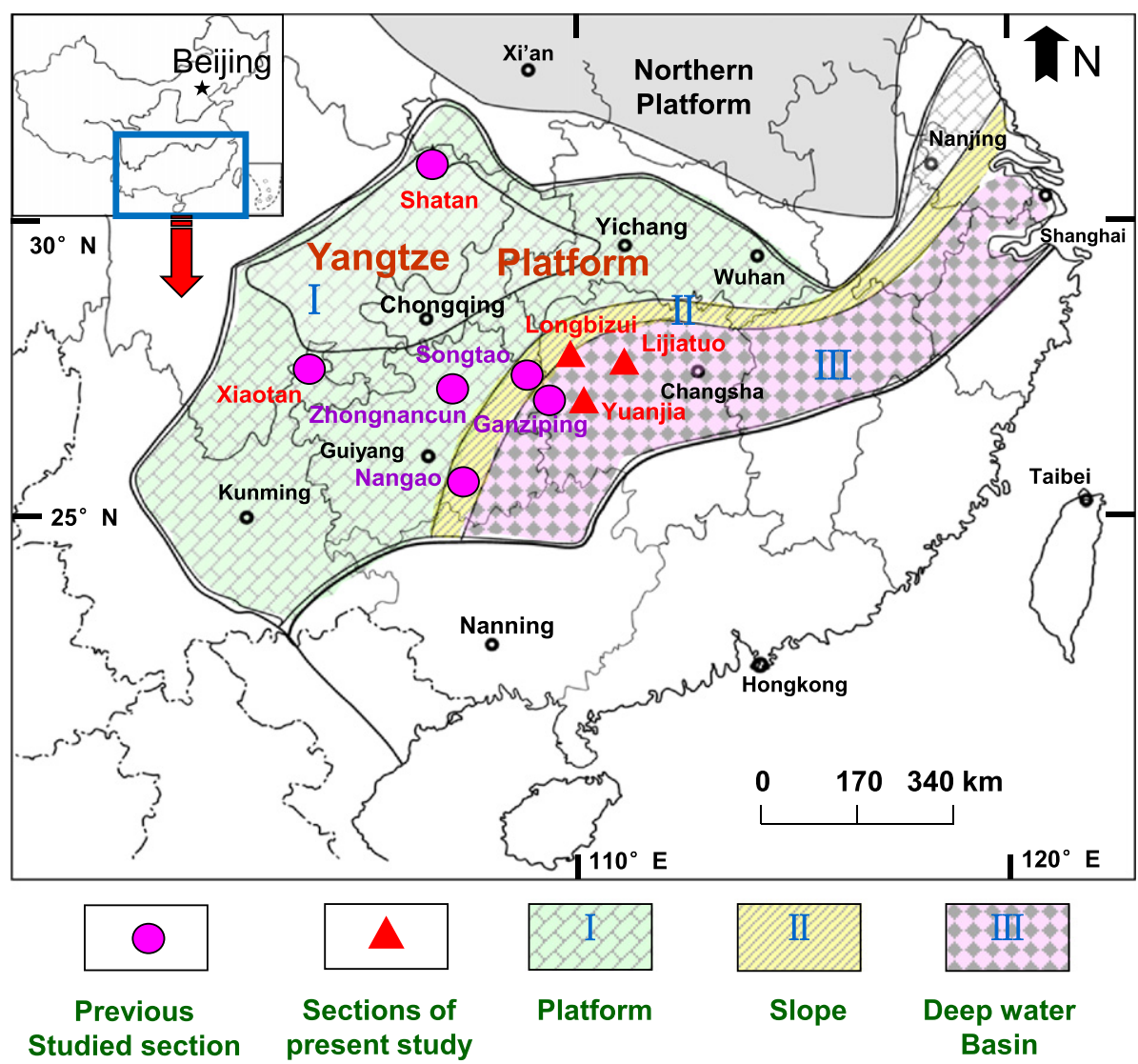

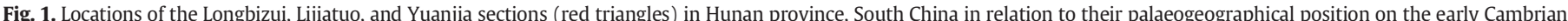
Yangtze Platform(I), the transition belt (II), and the basin belt (III) (compiled after Steiner et al., 2001).

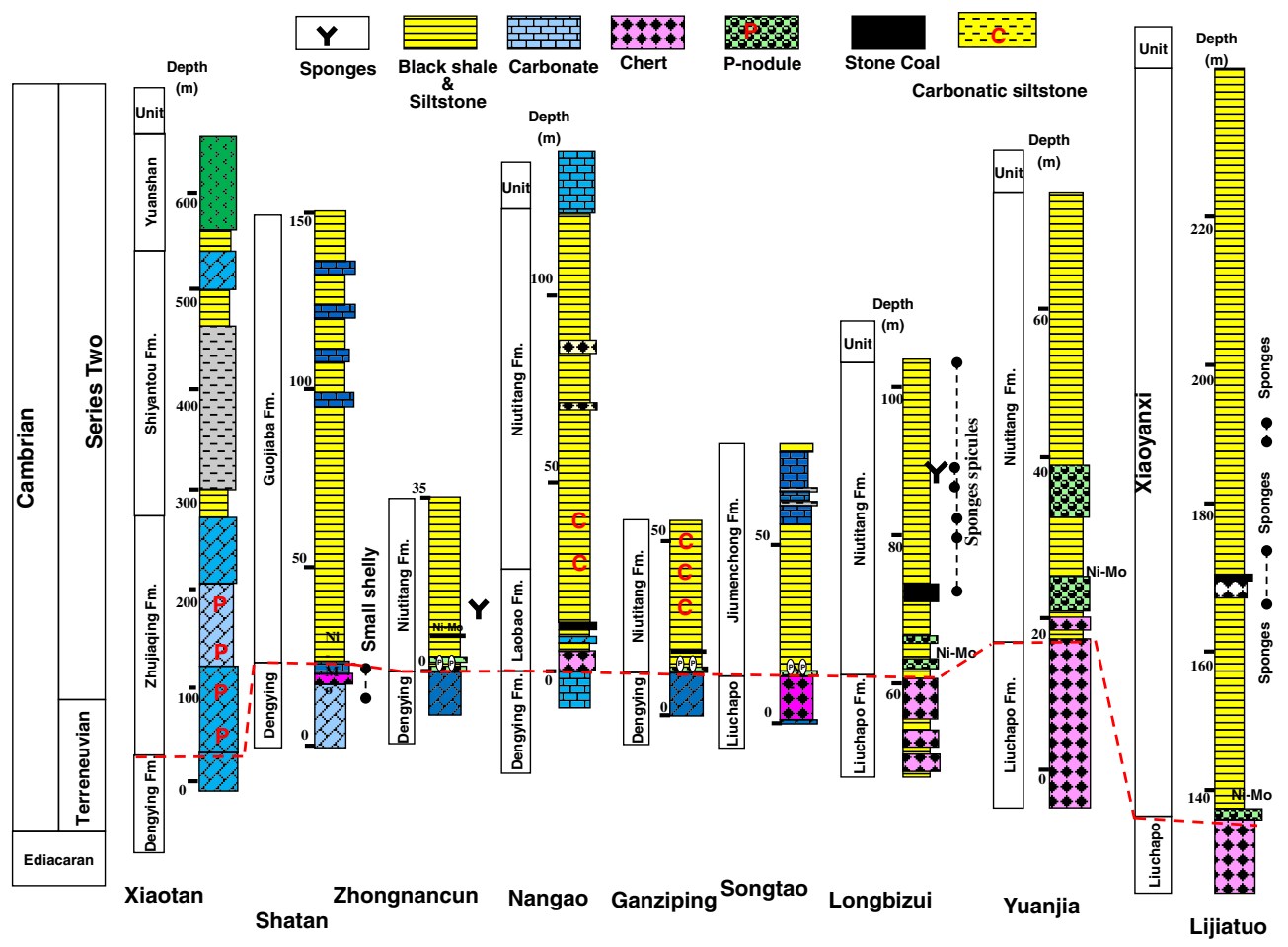

Fig. 2. Sketch chart showing correlations of the Lower Cambrian sections from the Yangtze Platform. 
or scavenged by organic matter (Felitsyn et al., 1998), and the distribution of kerogen-derived REE is believed to reflect characteristics of (near-) surface waters (Pi et al., 2008, 2013).

In this paper, high-resolution geochemical profiles (REE, trace elements) measured on kerogen and bulk rock are presented for three sections (Lijiatuo, Longbizui, and Yuanjia) in Hunan Province, South China. These sections comprise both the slope or transitional facies and the basinal facies of the Yangtze Platform. The objective of this study is to better constrain local vs. regional geochemical conditions during deposition. A focus is placed on the redox state of the water column along a facies gradient of the Yangtze marine platform.

\section{Sampling localities and studied material}

Samples were collected from the Longbizui, Lijiatuo, and Yuanjia sections in Hunan Province, South China (Fig. 1), representing both the slope/transitional and the basinal facies of the Yangtze Platform. Generally, the lower part of all three sections (equivalent to the Late Ediacaran to the Cambrian Stage 2) contains chert as well as siliceous and phosphatic shales, whereas the middle to upper part is dominated by black shales, siltstones, and subordinate occurrences of dolostones (equivalent to the early Stage 3 of Cambrian Series 2) (Guo et al., 2013).
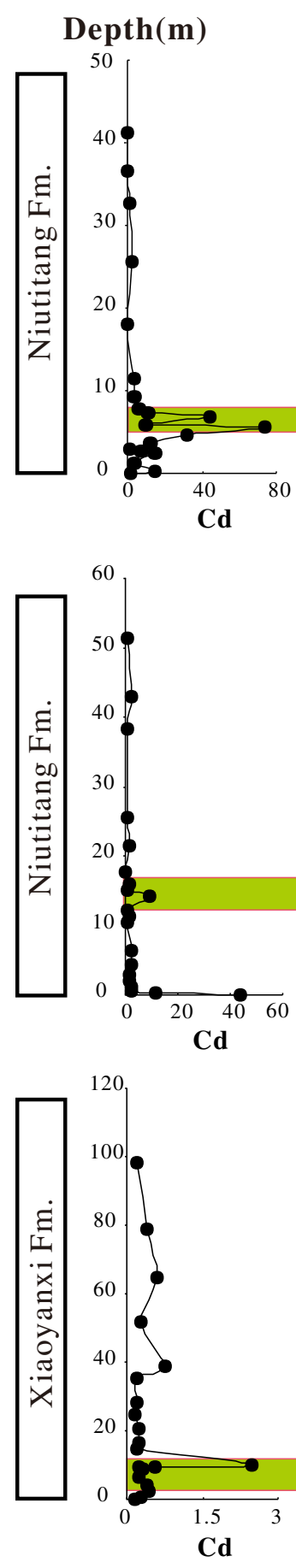

\section{Longbizui}

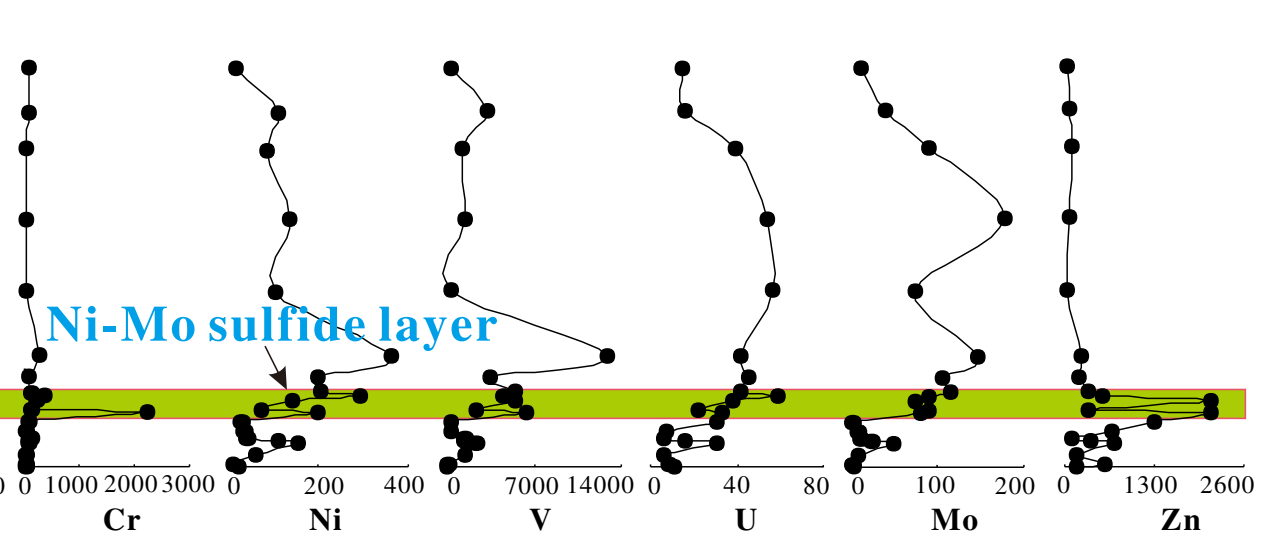

Yuanjia

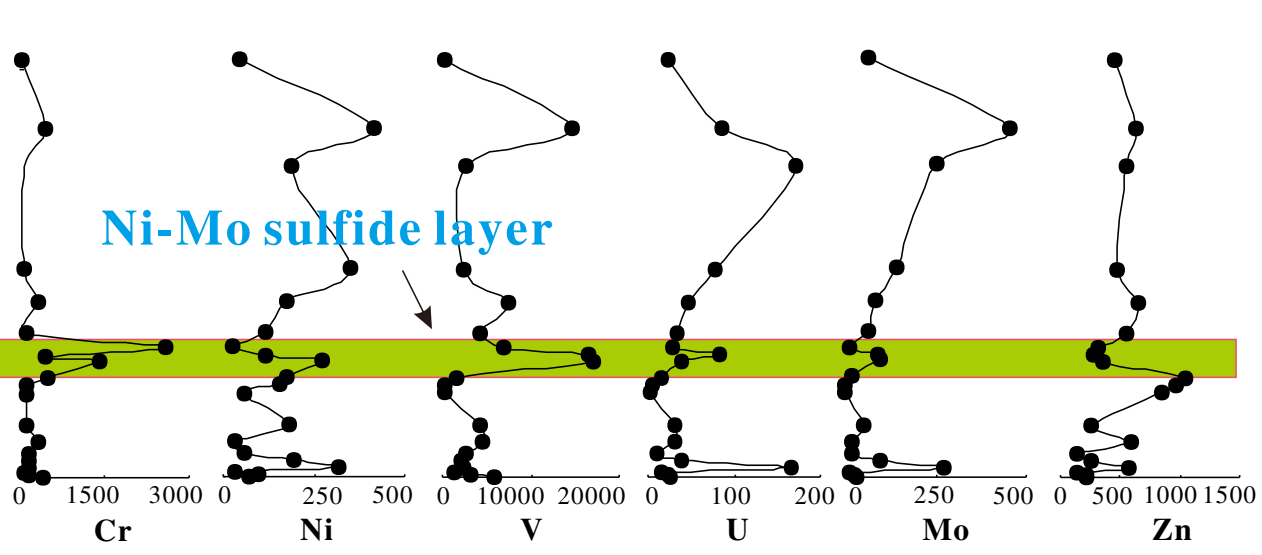

Lijiatuo

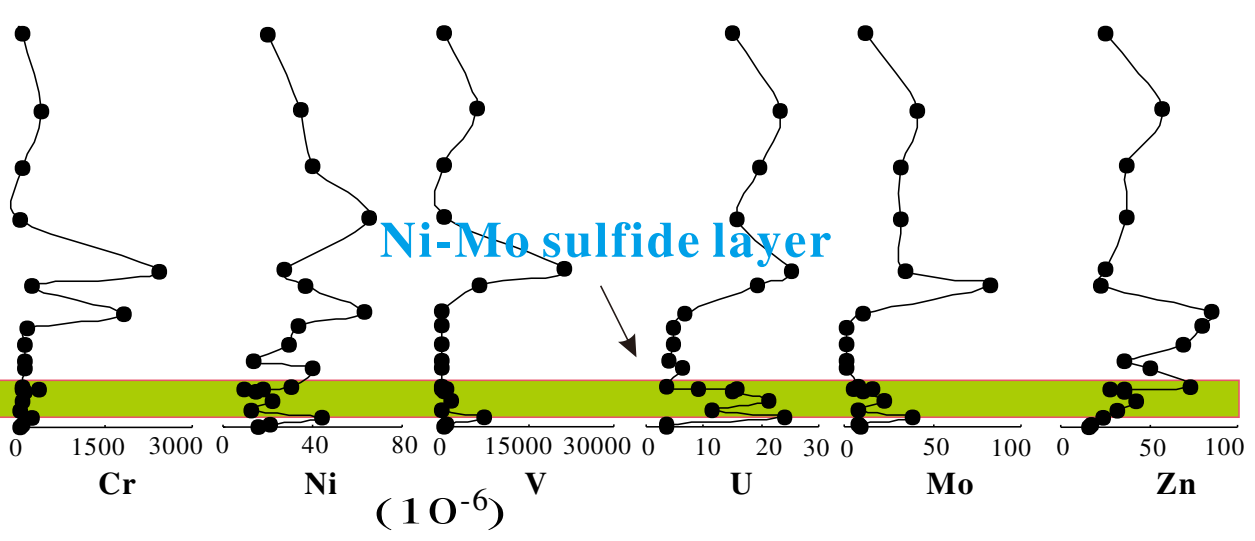

Fig. 3. Stratigraphic distribution of trace element concentrations from black shales (bulk rocks) for the Longbizui, Yuanjia, and Lijiatuo sections. 
The lower parts of the ca. $50 \mathrm{~m}$ thick Longbizui section, the ca. $80 \mathrm{~m}$ thick Yuanjia section, and the approximately $120 \mathrm{~m}$ thick Lijiatuo section consist of black chert of the Liuchapo Formation, overlain by gray to black shales of the Niutitang Formation. The base of the Niutitang Formation is defined by a horizon rich in phosphatic nodules and a sulfide layer enriched in Ni-Mo-PGEs (Pan et al., 2004; Jiang et al., 2007; Lehmann et al., 2007; Wille et al., 2008). The upper parts of the sections contain mainly gray to black shales rich in sponge spicules (Guo et al., 2013).

The correlation of these sections across the Yangtze Platform is shown in Fig. 2 (Pan et al., 2004; Guo et al., 2007a, 2007b; Yang et al., 2007; Guo et al., 2013; Och et al., 2013; Pi et al., 2013).

\section{Methods}

Black shale samples were crushed and pulverized (200 mesh). 58 samples showing relatively high total organic carbon (TOC) contents were selected for analysis of REE and trace elements. REE contents were analyzed solely from kerogen, and trace elements were analyzed both for kerogen and bulk rock.

The extraction of kerogen was performed following the procedure established by Fu and Qing (1995). Briefly, $1 \mathrm{~g}$ of sample powder was reacted in a teflon centrifuge tube with $5 \mathrm{ml}$ of $18 \% \mathrm{HCl}$. The solution was maintained at a temperature of $60-70{ }^{\circ} \mathrm{C}$ for $4 \mathrm{~h}$ in a water bath and thereafter washed and centrifuged. The process of heating and centrifugation process were conducted two times. Subsequently, $5 \mathrm{ml}$ of HF (40\%) was added to the solution in the centrifuge tube, and the reaction continued at a temperature of $60-70^{\circ} \mathrm{C}$ for $4 \mathrm{~h}$. Subsequent cleaning and centrifuging was again carried out twice for each sample. The sample residue was washed repeatedly with deionized water until $\mathrm{pH} 7$ was reached, and then dried. For kerogen digestion, $0.05 \mathrm{~g}$ of dry kerogen residue was dissolved in $5 \mathrm{ml}$ concentrated $\mathrm{HNO}_{3}$ in a PFA/Teflon beaker. The beakers were then placed in steel cans and subjected to high temperature $\left(190^{\circ} \mathrm{C}\right)$ and high pressure. After $48 \mathrm{~h}$, the solution was dried on a hotplate. The residues were fully digested using a mixture of concentrated $5 \mathrm{ml} \mathrm{HNO}_{3}$ and $1 \mathrm{ml} \mathrm{HClO}_{4}$ at $120{ }^{\circ} \mathrm{C}$ on a hotplate. After evaporation, the material was re-dissolved in $5 \mathrm{ml} 20 \% \mathrm{HNO}_{3}$ and placed into steel cans at high temperature $\left(190{ }^{\circ} \mathrm{C}\right)$ and pressure for $4 \mathrm{~h}$. After cooling, the solution was diluted to $50 \mathrm{ml}$ with double distilled water.

Preparation for rare earth and trace element analyses of bulk rock samples followed the method of Gao et al. (2003). $50 \mathrm{mg}$ sample powder were leached with $1 \mathrm{ml}$ of concentrated HF in a PFA/teflon beaker that was heated to $\sim 120^{\circ} \mathrm{C}$ in order to remove excess Si. After evaporation, the residues were fully digested using a mixture of concentrated $1 \mathrm{ml} \mathrm{HNO}$ and $2 \mathrm{ml} \mathrm{HF}$. Thereafter, the beakers were placed in steel cans and subjected to high temperature $\left(190^{\circ} \mathrm{C}\right)$ and high pressure treatment. After $48 \mathrm{~h}$, the solution was evaporated on a hotplate at $120{ }^{\circ} \mathrm{C}$. The residue was leached with $5 \mathrm{ml}$ concentrated $\mathrm{HNO}_{3}$ and dried again. Then, $1 \mathrm{ml}$ of concentrated $\mathrm{HClO}_{4}$ was added, and the sample dried to remove the rest of the HF. Finally, the residues were redissolved in $5 \mathrm{ml} 20 \% \mathrm{HNO}_{3}$ after drying at $\sim 140{ }^{\circ} \mathrm{C}$ for a couple of hours, and then diluted to $50 \mathrm{ml}$ with double distilled water.

Rare earth and trace elements were measured via ICP-MS, and Al, Ba, and Fe were analyzed with ICP-OES at the Institute of Geographic Sciences and Natural Resource Research, Chinese Academy of Sciences, Beijing. Analytical precision for elemental concentrations was generally better than $5 \%$. REE concentrations were normalized to PAAS (McLennan, 2001) and $\mathrm{Ce} / \mathrm{Ce}^{*}=\mathrm{Ce}_{\mathrm{N}} /\left(1 / 2 \mathrm{La}_{\mathrm{N}}+1 / 2 \mathrm{Pr}_{\mathrm{N}}\right), \mathrm{Eu} / \mathrm{Eu}^{*}=$ $\mathrm{Eu}_{\mathrm{N}} /\left(1 / 2 \mathrm{Sm}_{\mathrm{N}}+1 / 2 \mathrm{Gd}_{\mathrm{N}}\right) \mathrm{Y} / \mathrm{Y}^{*}=\mathrm{Y}_{\mathrm{N}} /\left(1 / 2 \mathrm{Dy}_{\mathrm{N}}+1 / 2 \mathrm{Ho}_{\mathrm{N}}\right), \mathrm{Pr} / \mathrm{Pr}^{*}=$ $\mathrm{Pr}_{\mathrm{N}} /\left(1 / 2 \mathrm{Ce}_{\mathrm{N}}+1 / 2 \mathrm{Nd}_{\mathrm{N}}\right)$ were calculated (Bau and Dulski, 1996).

\section{Results and discussion}

\subsection{Trace element geochemistry}

All sections exhibit similar trace element abundances in the order $\mathrm{Ag}>\mathrm{As}>\mathrm{Mo}>\mathrm{Ni}>\mathrm{Pb}>\mathrm{Sc}$. Moreover, all sections exhibit similarities in trace element abundance with considerable enrichment of Ag, As, $\mathrm{Ba}, \mathrm{Cu}, \mathrm{Ga}, \mathrm{Mo}, \mathrm{Ni}, \mathrm{U}$, and V (Fig. 3) relative to the upper continental crust (UCC; Taylor and McLennan, 1985; McLennan, 2001). Bulk rock average concentrations of $\mathrm{V}, \mathrm{U}$, and Mo display significant enrichments (Fig. 3), whereas the concentrations of these elements in kerogen are only 0.5-4.1 (V), 1.4-2.3 (U), and 5.9-38.1 (Mo) times the concentrations in the UCC, respectively (Fig. 4). These trace elements are mainly enriched in the lower part of the sections (Fig. 3), and the Ni-Mo sulfide layer was defined depending on trace element enrichment, lithology and carbon isotopic evolution. Differences in trace element abundances are found between bulk rock and kerogen with $\mathrm{U}$ and $\mathrm{V}$ being more enriched in bulk rock samples than in the respective kerogen samples.

The contents of redox-sensitive elements such as Ni, U, V, and Mo; their ratios ( $\mathrm{Th} / \mathrm{U}=2$ (Wignall and Twitchett, 1996), V/Sc $=24$ (Kimura and Watanabe, 2001), and $\mathrm{V} / \mathrm{Cr}=2$ (Rimmer, 2004)), and the correlation of the $\mathrm{V} / \mathrm{Al}, \mathrm{U} / \mathrm{Al}$, and $\mathrm{Mo} / \mathrm{Al}$ values with the TOC concentrations are useful for tracing paleoredox conditions (Yarincik et al., 2000; Algeo and Maynard, 2004; Tribovillard et al., 2006; Guo et al., 2007b). Moreover, geochemical evidence (e.g., U/Th, V/Cr, V/Sc, and $\mathrm{V} / \mathrm{V}+\mathrm{Ni}$ ) for oxic, dysoxic, and anoxic conditions has been widely used in marine shale (Powell et al., 2003; Powell, 2009; McKirdy et al., 2011). Organic matter is enriched with $U$ and $V$ under anoxic conditions. Because of the compositional difference between kerogen and bulk rock, the ratios of the redox-sensitive elements (such as $\mathrm{Th} / \mathrm{U}=2$,

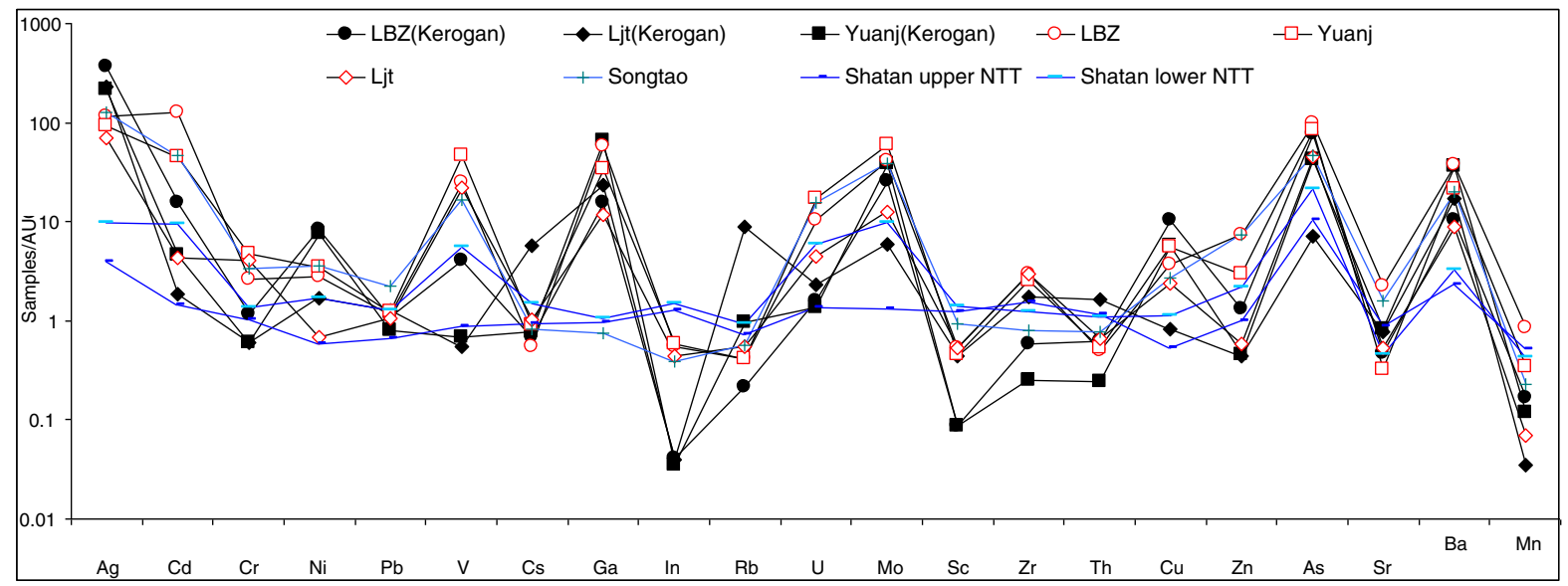

Fig. 4. Concentrations of trace elements of black rock series from the Longbizui, Lijiatuo, and Yuanjia sections. The values were normalized to average upper crust (Mclennan, 2001). 

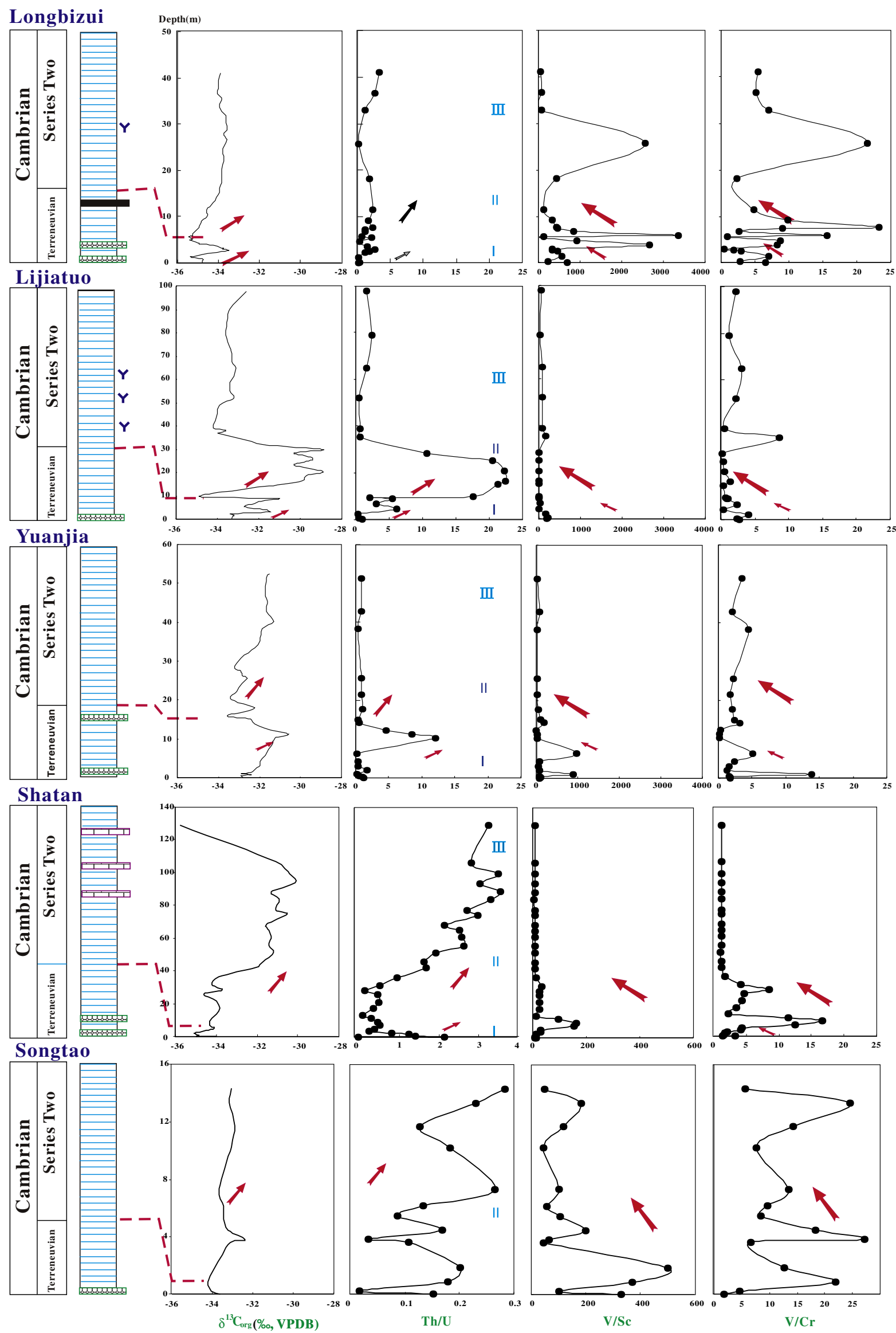

Fig. 5. Variation of Th/U, $\mathrm{V} / \mathrm{Sc}, \mathrm{V} / \mathrm{Cr}$, and $\delta^{13} \mathrm{C}_{\text {org }}$ for the sections; $\delta^{13} \mathrm{C}_{\text {org }}$ data from Guo et al. (2013). 
$\mathrm{V} / \mathrm{Sc}=24$, and $\mathrm{V} / \mathrm{Cr}=2$ ) cannot be used to accurately distinguish the oxic/anoxic boundary. However, the variations in the ratios of the redox-sensitive elements in kerogen may reflect the redox conditions of bottom seawater. Th/U values from kerogen (Fig. 5) in the sections increase from minimum values at the bottom of the sections to maximum values at the top (Fig. 5). Th/U values initially rise followed by a steep fall in phase I and II, and gradual increase in phase III, while the V/Sc and $\mathrm{V} / \mathrm{Cr}$ values show the opposite trend (Fig. 5).

Correlations between the concentrations of $\mathrm{V}, \mathrm{U}, \mathrm{Mo}$, and TOC are significant for tracing redox conditions (Algeo and Maynard, 2004; Tribovillard et al., 2006). Under anoxic conditions, V, U, Mo, and TOC contents show positive correlations. These correlations tend to decrease or disappear in oxic or euxinic environments. The correlations between TOC, V, U, and Mo are relative weak in the Longbizui section (Fig. 6), likely due to $\mathrm{H}_{2} \mathrm{~S}$ input during deposition (Algeo and Maynard, 2004). At the bottom of phase II, one sample (LBZ581) from the Ni-Mo polymetallic layer is situated in the euxinic zone (Algeo and Maynard, 2004) in each diagram of Fig. 6, suggesting euxinic depositional conditions. The Lijiatuo section shows obvious positive correlations between TOC, V, U, and Mo (Fig. 6) suggesting anoxic conditions. The sample Ljit 560 taken from the euxinic zone shows clear correlations between $\mathrm{V}, \mathrm{U}, \mathrm{Mo}$, and TOC (Fig. 6). Also, the Yuanjia section exhibits the depositional conditions of an anoxic and euxinic environment at the bottom of phase II.

Other areas on the Yangtze Platform show the same variations in trace element concentrations (Fig. 7) indicating two oxygenated events with transient euxinic conditions in the Early Cambrian.

\subsection{Rare earth element distributions}

Based on rock type, the lowest average content of $\Sigma$ REE in kerogen was detected in siliceous shale ( $7 \pm 1 \mathrm{ppm}, \mathrm{n}=2$ ), followed by phosphatic shale $(119 \pm 112 \mathrm{ppm}, \mathrm{n}=5)$ and chert ( $271 \mathrm{ppm}, \mathrm{n}=1)$. Black shale is characterized by the highest, but variable, $\Sigma$ REE content of $358 \pm 670 \mathrm{ppm}(\mathrm{n}=50)$.

The high REE contents of extracted kerogen samples (individual samples with $\Sigma>1000 \mathrm{ppm}$ ) are consistent with data from Proterozoic

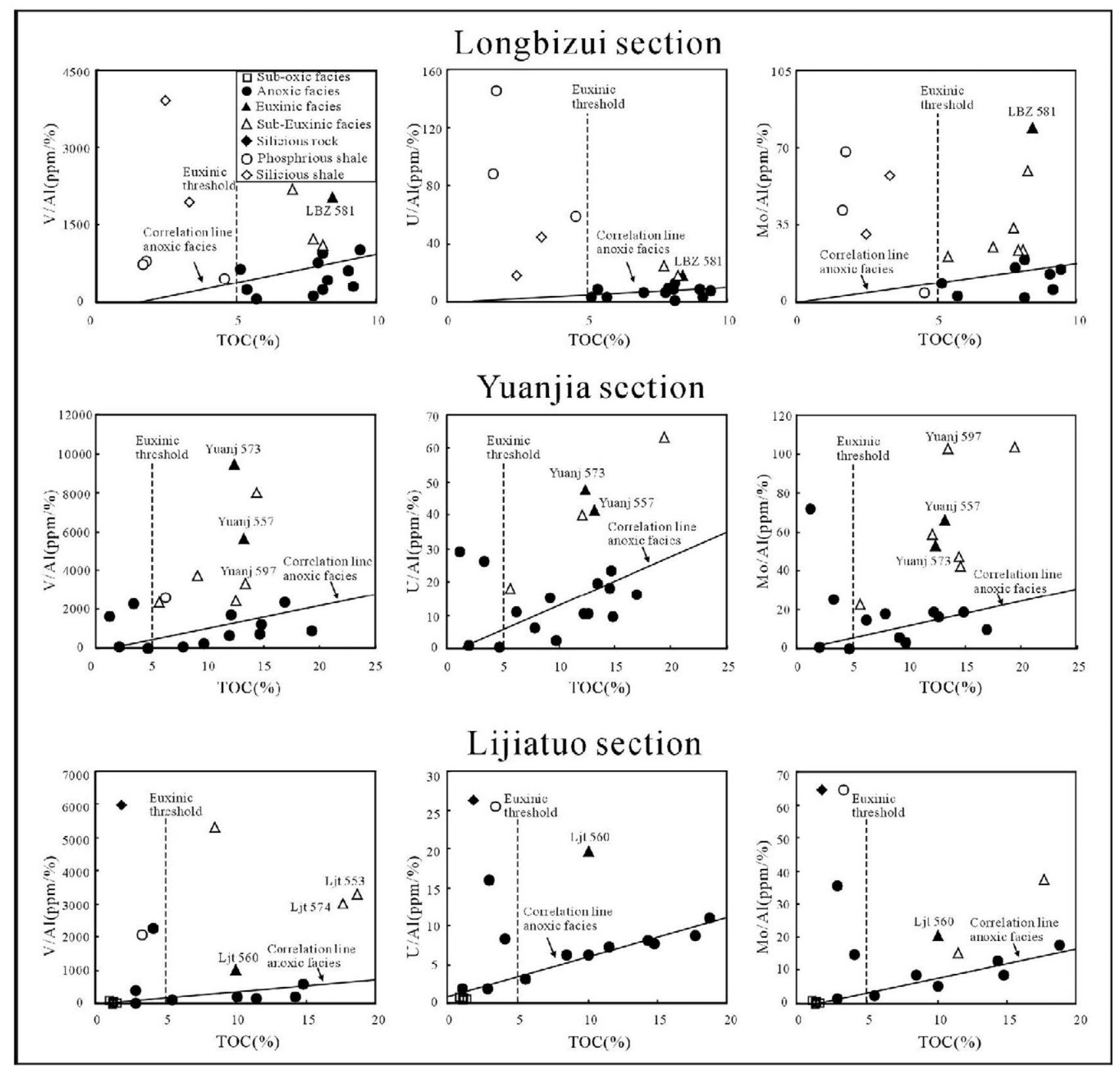

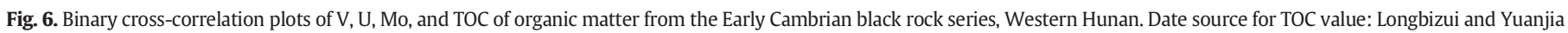
sections (Guo et al., 2013), Lijiatuo section (Guo et al., 2007a). 

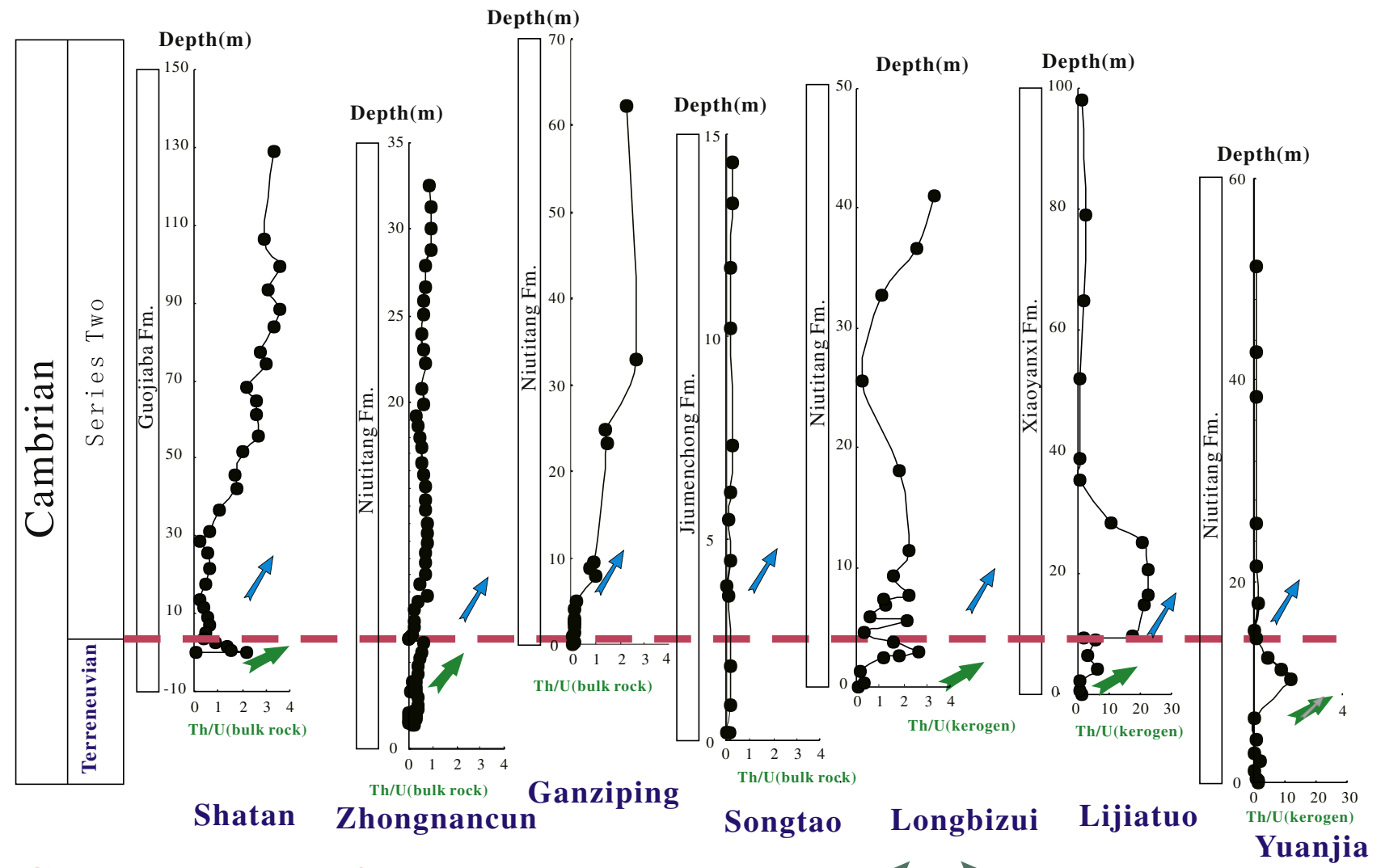

\section{Carbonate platform}
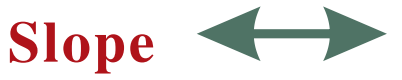

Basin

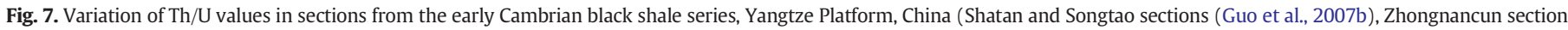
(Pi et al., 2013), Ganziping section (Pan et al., 2004).

stratiform kerogen (Mossman et al., 1993). In addition, the PAASnormalized REE distribution patterns of almost all samples are characteristic of seawater (Fig. 8). The distribution patterns show a progressive enrichment toward heavier REE (average values of $\mathrm{La}_{N} / \mathrm{Yb}_{N}, \mathrm{Gd}_{N} / \mathrm{Yb}_{\mathrm{N}}$, and $\mathrm{Dy}_{\mathrm{N}} / \mathrm{Yb}_{\mathrm{N}}$ are $0.3,0.45$, and 0.54 , respectively, Tables 1 and 2), depletion of Ce (except Ljt561 and Ljt563, which may be affected by strongly reducing conditions), positive anomalies of $\mathrm{Y}\left(\mathrm{Y} / \mathrm{Y}^{*}\right.$ values range from 1.18 to 3.77), and a slight enrichment of Gd. In addition, there is no obvious relationship between $\Sigma$ REE and $\mathrm{Al}$, which suggests that the composition in the kerogen was not affected by terrigenous detritus.

Organic matter in black rock series mainly derives from algae, acritarchs, and plankton in shallow water (Wu et al., 1999a). These organisms exchanged carbon and other nutrients with the surrounding environment through metabolism and respiration and reached equilibrium and saturation after a certain period of time. This process led to a REE pattern of seawater in organic matter (Pi et al., 2008). Decay and re-mineralization of organic matter may have released REE to the seawater. Sedimentation and diagenesis may change the values of $\mathrm{Ce} / \mathrm{Ce}^{*}$ in organic matter, with progressively more Ce-enriched, Eu-depleted, and decreasing DyN/SmN ratios (Shields and Stille, 2001). However, there are no obvious relationships between $\mathrm{Ce} / \mathrm{Ce}^{*}$ and $\mathrm{Eu} / \mathrm{Eu}^{*}, \mathrm{\Sigma} \mathrm{REE}$ values and DyN/SmN ratios, which indicates that REE scavenging after deposition was weak (Tables 1 and 2). The shale-normalized REE in bulk rock always displays a flat pattern (Guo et al., 2007b). Moreover, kerogen (accounting for more than $90 \%$ in the organic matter) (Hu et al., 1999) shows relatively stable chemical characteristics, which are hardly disturbed by environmental conditions. Data from the investigated sections show seawater-like REE distribution patterns (Fig. 8), which suggest that REE of organic matter (authigenic component) were directly derived from shallow seawater (Pi et al., 2008, 2013).

\subsection{Cerium anomalies}

Depending on the circumstances, cerium (Ce) exists in either trivalent or tetravalent forms. Tetravalent $\mathrm{Ce}$ is prone to be absorbed by Mn-oxide and hydroxides under oxic conditions (Bau et al., 1996). As a result, $\mathrm{Fe}-\mathrm{Mn}$ sediments are enriched in $\mathrm{Ce}$, showing positive anomalies in comparison with seawater exhibiting relative Ce depletion (Bau et al., 1996). In addition, the variation of the Ce content is related to oxygen concentration and dissolution of Mn-rich particles (Ling et al., 2013). A positive correlation between $\mathrm{Ce} / \mathrm{Ce}^{*}$ values and $\mathrm{O}_{2}$ concentrations, a negative correlation between $\mathrm{Ce} / \mathrm{Ce}^{*}$ values and Mn contents of particles in the upper water column of the modern Black Sea, and increasing $\mathrm{Ce} / \mathrm{Ce}^{*}$ values in the Early Cambrian sections of this study can be seen (Fig. 9).

Negative Ce anomalies in the sections range from 0.29 to 0.92 (Tables 1 and 2), mainly representing organic matter derived from the upper layer of the water column. In particular, the $\mathrm{Ce} / \mathrm{Ce}^{*}$ values gradually increase from the lower part of sections to the top; the average $\mathrm{Ce} / \mathrm{Ce}^{*}$ values from the lower parts of the Longbizui, Lijiatuo, and Yuanjia sections (Terreneuvian) are $0.58(n=9), 0.53(n=7)$, and $0.45(n=12)$, respectively. However, the values from the upper parts (series two) rise to $0.76(\mathrm{n}=11), 0.82(\mathrm{n}=12)$, and $0.66(\mathrm{n}=7)$, respectively (Fig. 9).

\subsection{Europium anomalies}

Europium in the surface water is trivalent, and only strongly reducing conditions can lead to positive Eu anomalies. But a hydrothermal input can also produce a positive Eu anomaly, and in this case, it is positively correlated with $\mathrm{Ba} / \mathrm{Nd}$ (Shields and Stille, 2001). However, the Eu anomalies can also be derived from Ba interference related to ICP-MS analytical techniques (Dulski, 1994). Ba/Nd and $\mathrm{Eu} / \mathrm{Eu}^{*}$ in kerogen 

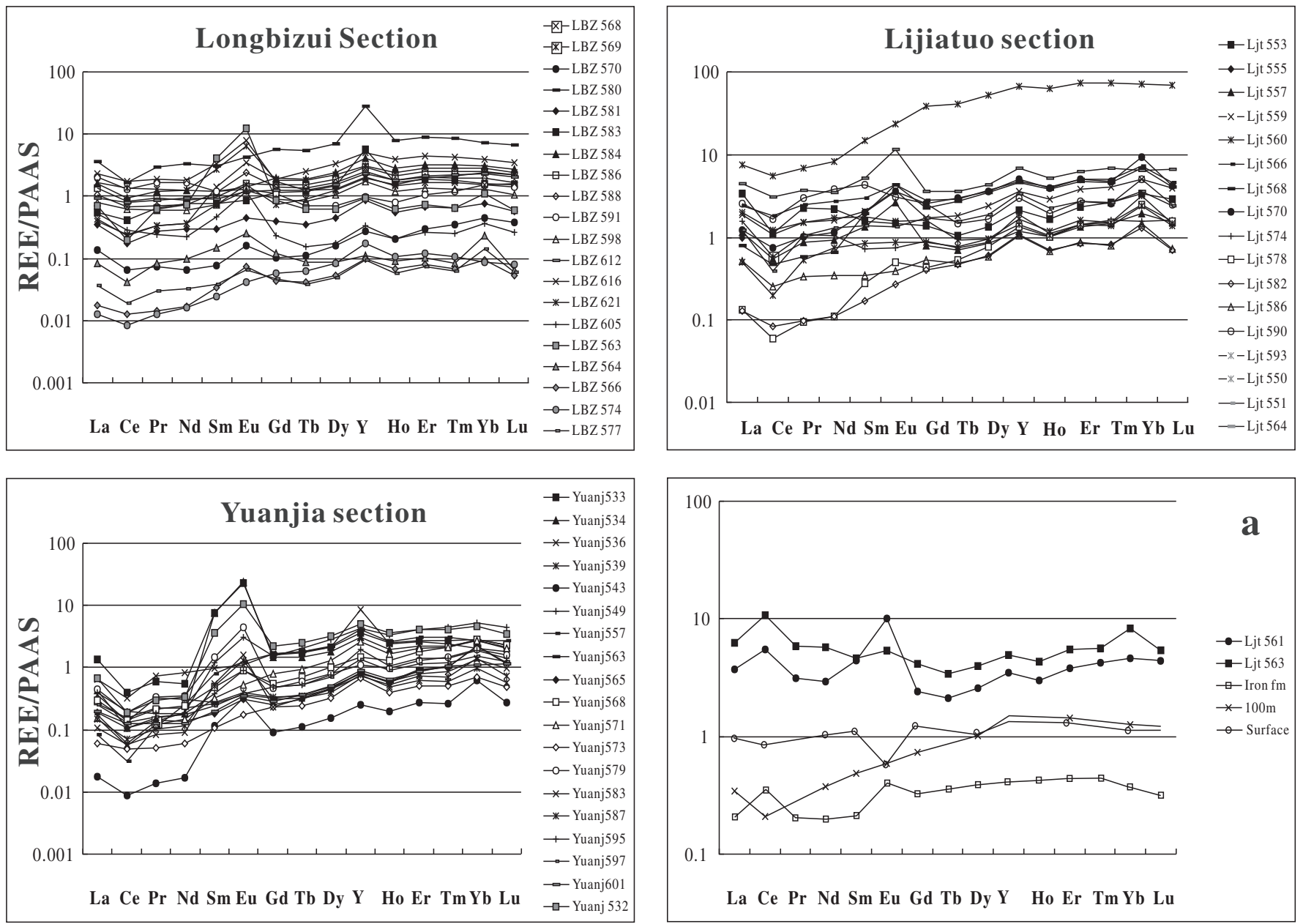

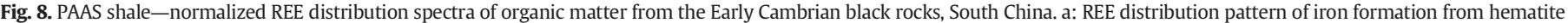
(Slack et al., 2007). Seawater REE pattern is defined by water samples at surface and $200 \mathrm{~m}$ depth in North Atlantic*10 ${ }^{6}$ (Elderfield and Greaves, 1982).
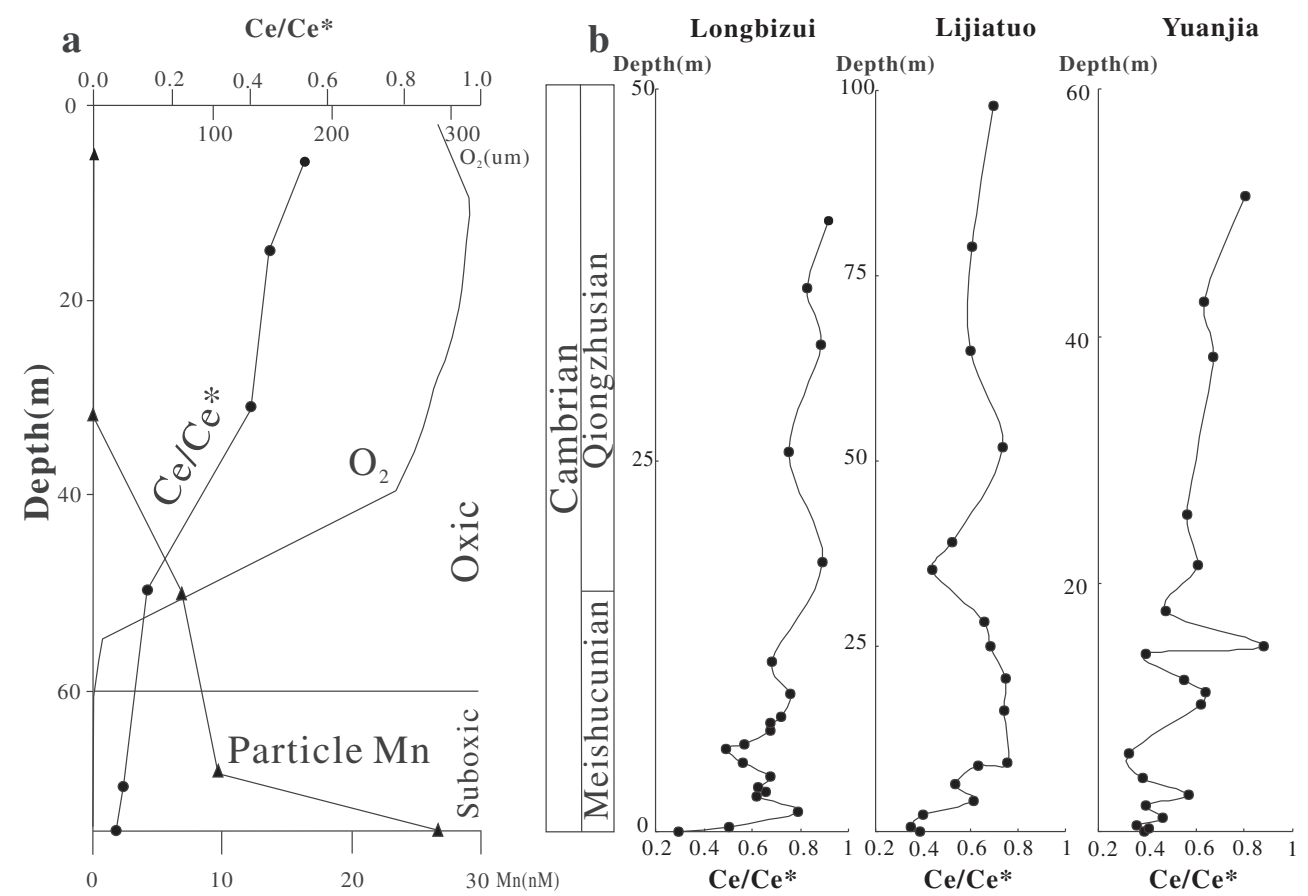

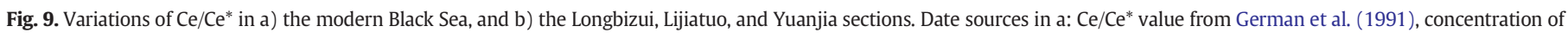
particle Mn from Lewis and Landing (1991), and concentrations of $\mathrm{O}_{2}$ from Luther et al. (1991). 

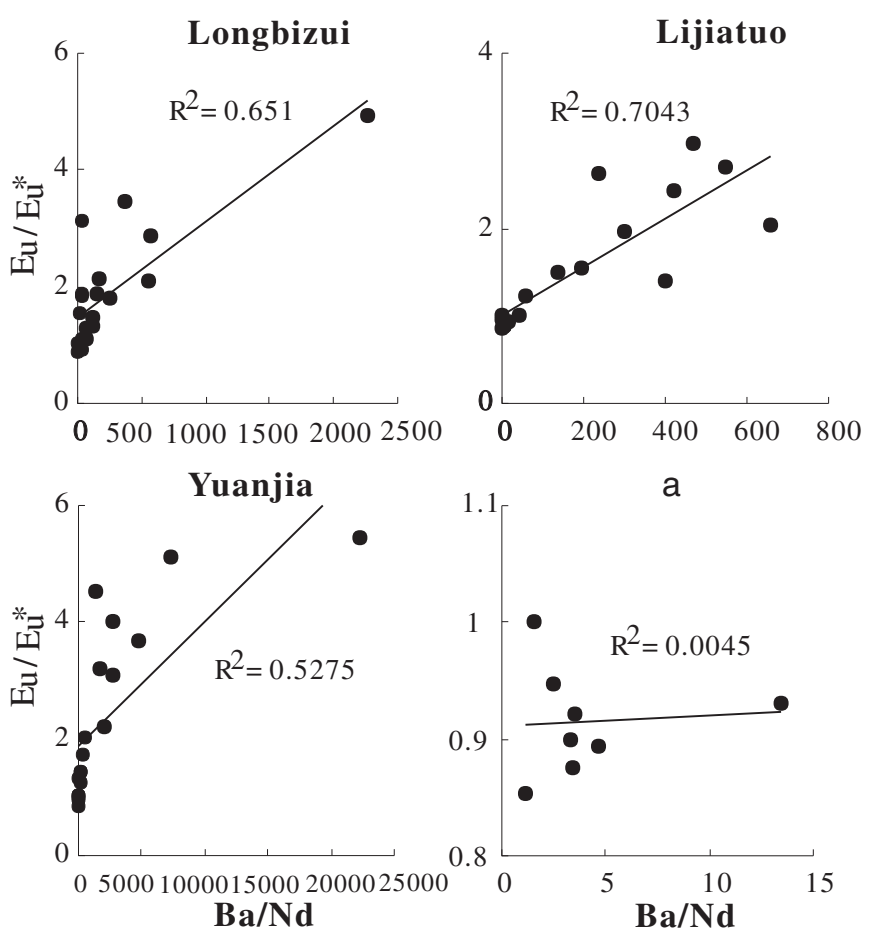

Fig. 10. Binary cross-correlation plots of $\mathrm{Ba} / \mathrm{Nd}$ and $\mathrm{Eu} / \mathrm{Eu}^{*}$ from the Early Cambrian black rocks, South China.

exhibit a positive correlation in the Longbizui, Lijiatuo, and Yuanjia sections (the correlation coefficients were $0.65(n=20), 0.70(n=19)$, and $0.53(\mathrm{n}=19)$, respectively; Fig. 10) and indicate that Eu (disturbed by $\mathrm{Ba}$ ) cannot reflect the original signature during deposition in the marine environment. However, there is no obvious correlation between $\mathrm{Ba} / \mathrm{Nd}$ and $\mathrm{Eu} / \mathrm{Eu}^{*}$ in samples with low Ba concentrations $(\mathrm{Ba} / \mathrm{Nd}<20)$, such as the Lijiatuo section $\left(R^{2}=0.004, n=8\right.$; Fig. 10a). The Eu/Eu* values of the low Ba concentration kerogen samples in the Longbizui, Lijiatuo, and Yuanjia sections range from 0.84 to 1.02 , which corresponds to the Eu characteristics of normal marine surface water. The lack of, or only weak, Eu anomalies point to the fact that REE in organic matter were derived from the upper water layer.

\subsection{Implication for the rise of oxygen}

Sedimentary organic matter is mainly derived from marine organisms of the upper seawater layer (Wu et al., 1999a, 1999b). The variations of the Ce content and the $\mathrm{Ce} / \mathrm{Ce}^{*}$ ratio are related to the dissolved oxygen concentration in shallow seawater and sea-level changes (Ling et al., 2013), both of which play a key role in the evolution of complex animals. The $\mathrm{Ce} / \mathrm{Ce}^{*}$ ratio decreases with depth (Fig. 9a) in the upper water layer of the modern ocean (Ling et al., 2013). Consequently, increasing $\mathrm{Ce} / \mathrm{Ce}^{*}$ ratios observed in the sections studied here suggest sea level fall (i.e. organic matter lived primarily in more shallow water), which would be consistent with a proposed transgressive flooding of the Yangtze Platform at beginning of the Cambrian (Goldberg et al., 2007; Guo et al., 2013; Feng et al., 2014), after which sea level fell. Alternatively, an increasing oxygen concentration in the shallow water may have led to the change of $\mathrm{Ce} / \mathrm{Ce}^{*}$ values (Ling et al., 2013). Thus, we infer that change of sea level plays a major role in the variation of the $\mathrm{Ce} / \mathrm{Ce}^{*}$ values and led to the increasing oxygen concentration of the bottom water. After the first oxidation event of the late Terreneuvian (i.e. the anoxic conditions in the bottom water rapidly changed to euxinic conditions, Fig. 5), the $\mathrm{Ce} / \mathrm{Ce}^{*}$ values show a transient decrease with sea-level rise in the lower part of the sections (Fig. 9). Subsequently, the sea-level fall (increasing $\mathrm{Ce} / \mathrm{Ce}^{*}$ values) led to the second oxidation event (Fig. 5) and oxic-suboxic conditions in the bottom seawater. Moreover, the change of redox conditions of bottom water may affect surface water. Wille et al. (2008) inferred that bottom seawater rich in $\mathrm{H}_{2} \mathrm{~S}$ may have reached the surface water in the Ediacaran-Early Cambrian period. Hence, the attenuation of the euxinic conditions at the sea bottom probably resulted in the increasing concentration of dissolved oxygen in the upper seawater. The negative $\mathrm{Ce}$ anomalies are mainly derived from the input of organic matter (Guo et al., 2007b; Pi et al., 2013). However, the same gradually increasing $\mathrm{Ce} / \mathrm{Ce}^{*}$ values with depth seen in kerogen can be observed in the profiles from bulk rocks of the Early Cambrian sections at the Yangtze platform (Fig. 11).

However, the similar gradually increasing $\mathrm{Ce} / \mathrm{Ce}^{*}$ values up-section seen in kerogen can be observed in the profiles from bulk rocks of the Early Cambrian sections of the Yangtze platform (Fig. 11), indicating a more reducing environment. The characteristics of the Ce anomalies are in apparent contradiction to other geochemical interpretations. Reconciling this conflict, Guo et al. (2007b) observed a significant negative Ce anomaly in black shale, which was proven to be deposited under anoxic environmental conditions, and concluded that negative $\mathrm{Ce}$

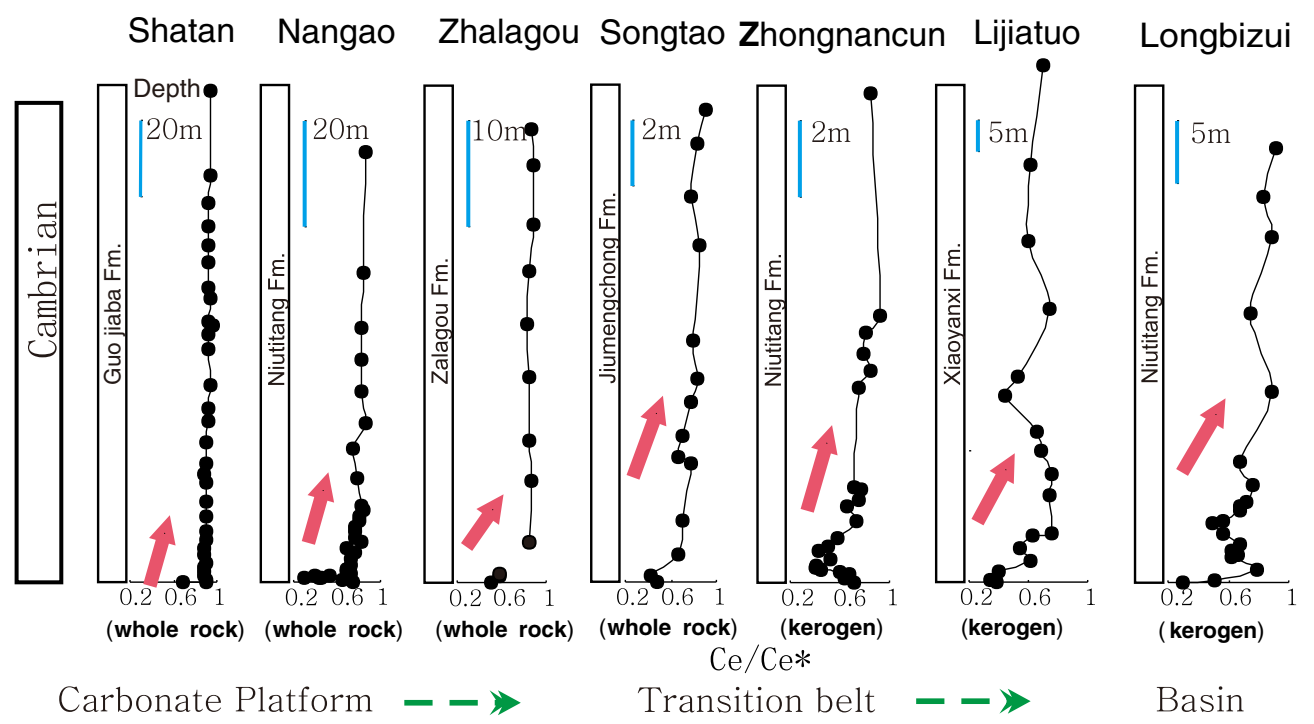

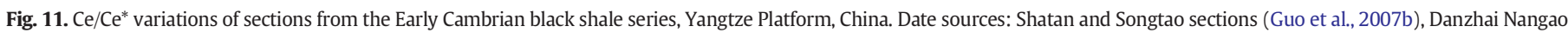
and Zhalagou sections (Yang et al., 2008), Zhongnancun section (Pi et al., 2013). 
anomalies might be derived from a marine environment that is above a mid-water redox level. Gradual oxidation of seawater leads to weaker $\mathrm{Ce}$ anomalies in kerogen and results in larger $\mathrm{Ce} / \mathrm{Ce}^{*}$ values in bulk rocks. The rapid change from the bottom of the Shatan section (carbonate platform) (moderate negative $\mathrm{Ce}$ anomalies, $\mathrm{Ce} / \mathrm{Ce}^{*}=0.68$ ) to the upper part of this section (lack of obvious Ce anomalies) (Fig. 11; Guo et al., 2007b), is probably caused by the interference of abundant nearly terrestrial detrital material, when conditions tended to suboxic or oxic.

The stratigraphic variations in the isotopic composition of organic carbon in the Ediacaran-Cambrian (Guo et al., 2013) are comparable to variations of the Th/U ratios (Figs. 5 and 7). The relatively low values of Th/U in stage 1 and lower stage 2 of the three sections correspond to more negative organic carbon isotope values. Moreover, a steep rise of $\mathrm{Th} / \mathrm{U}$ values corresponds to the positive shift in $\delta^{13} \mathrm{C}_{\mathrm{org}}$, which suggests an increase in the concentration of dissolved oxygen (Goldberg et al., 2007; Guo et al., 2007a). This change to less negative $\delta^{13} C_{\text {Corg }}$ values reflects the enhanced burial of organic matter (Guo et al., 2013). Two levels with increasing $\delta^{13} \mathrm{C}_{\mathrm{org}}$ values would also be consistent with the two proposed oxidation events in the Terreneuvian and early Epoch 2 of the Cambrian.

The correlation between the concentrations of redox-sensitive elements (Figs. 5 and 7) and TOC, V, U, and Mo concentrations (Fig. 6)
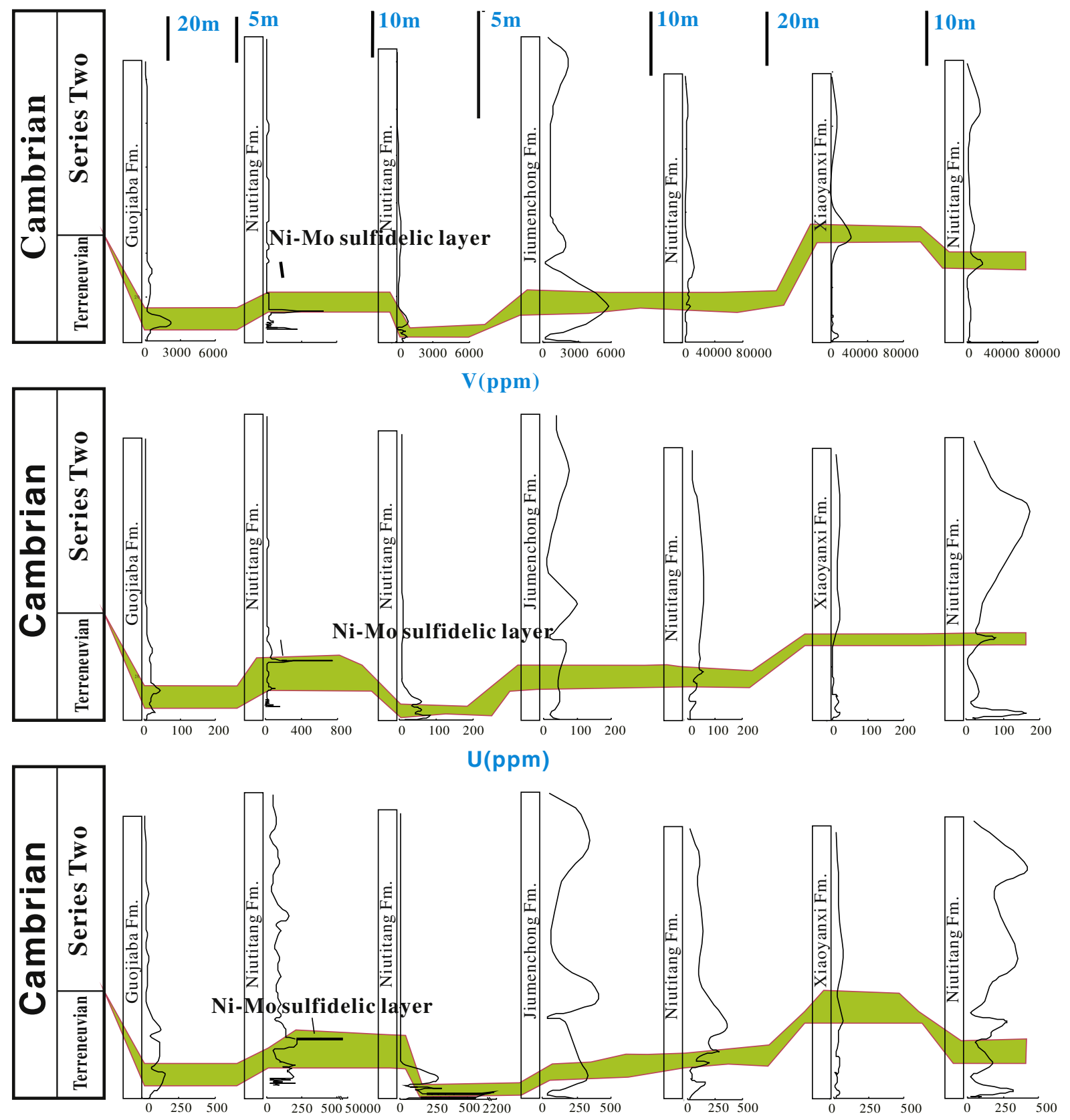

-Mossulfidelic layer

$\mathrm{Ni}(\mathrm{ppm})$

Shatan Zhongnancun Ganziping Songtao Longbizui Lijiatuo
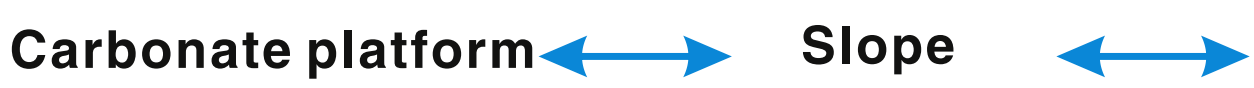

Yuanjia

Basin

Fig. 12. Comparison of variations from the different sections ranging from platform through slope to basin during the Early Cambrian of the Yangtze Platform (Pan et al., 2004; Guo et al., 2013; Pi et al., 2013). 
after the first oxidation event of the upper Cambrian Stage 2 of Series 1 shows that the bottom water became rapidly euxinic, which is supported by iron speciation data (Feng et al., 2014) and the minimum $\delta^{13} \mathrm{C}_{\mathrm{Corg}}$ values in this area (Fig. 5). Moreover, Mo/TOC and $\delta^{34} \mathrm{~S}$ values show euxinic conditions in the Longbizui section (Och et al., 2015). Total organic carbon and total sulfur correlations indicate sulfidic conditions in the lower Niutitang Formation of the Yuanjia section (Guo et al., 2013). Thus, euxinic conditions prevailed during the Early Cambrian as shown for the three studied sections. This process led to the deposition of a stable Ni-Mo polymetallic layer, which is widely distributed in South China. In addition, trilobites occur above this $\mathrm{Ni}$-Mo polymetallic layer (Yang et al., 2003; Zhu et al., 2003). Subsequently, the second oxidation event caused oxic-suboxic conditions in the bottom seawater.

Data from different facies belts of the Yangtze Platform suggest that the ancient marine environment in the Early Cambrian varied from strongly anoxic (or euxinic) to suboxic, and then to oxic caused by a sea-level fall and increasing oxygen concentrations. Two distinct oxidation events are discernible: the first one occurred in the late Terreneuvian; the second one, which took place in early Epoch 2 of the Cambrian, led to a richer biosphere and, hence, the "Cambrian Explosion".
4.6. Implication for the Ni-Mo polymetallic layer and hydrothermal activity

Trace element contents in kerogen are clearly different from bulk rocks (Fig. 4). Cd, Cr, V, In, U, Mo, Li, Sc, Zr, Zn, and As concentrations are higher in bulk rocks, but $\mathrm{Ag}, \mathrm{Ni}$, and $\mathrm{Tl}$ tend to be enriched in organic matter. Algeo and Maynard (2004) consider that Ni is mainly enriched in organic matter that has not been influenced by the environmental change from anoxic to euxinic conditions. As a result, the Ni concentration in kerogen is higher than in bulk rocks (Tables 1 and 2). In anoxic environments, organic matter in the sediment absorbs $\mathrm{U}, \mathrm{V}$, and $\mathrm{Zn}$. However, where $\mathrm{H}_{2} \mathrm{~S}$ is present in the water column, $\mathrm{U}, \mathrm{V}$, and $\mathrm{Zn}$ become widely enriched in sulfide under euxinic conditions (Algeo and Maynard, 2004). The U, V, and Zn contents in bulk rocks are much higher than those in kerogen indicating euxinic conditions. The $\mathrm{V}$ and Mo average contents in kerogen are 190.47 ppm and 34.78 ppm, respectively. The kerogen samples are slightly more enriched compared to the sediments deposited under strongly reducing conditions in the Black Sea (V = 141 ppm, Mo = 21 ppm; Calvert and Pedersen, 1993). The results are in accordance with Early Cambrian seawater, which showed more reducing conditions than modern seawater (Lehmann et al.,

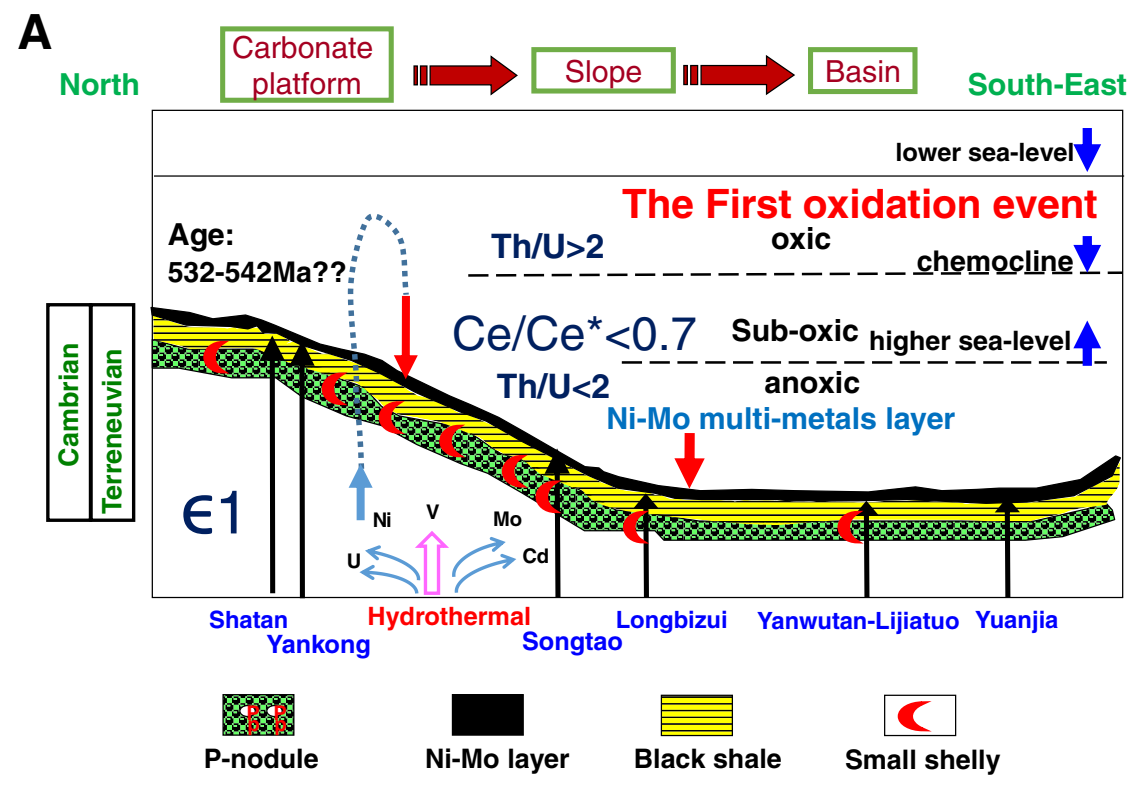

B

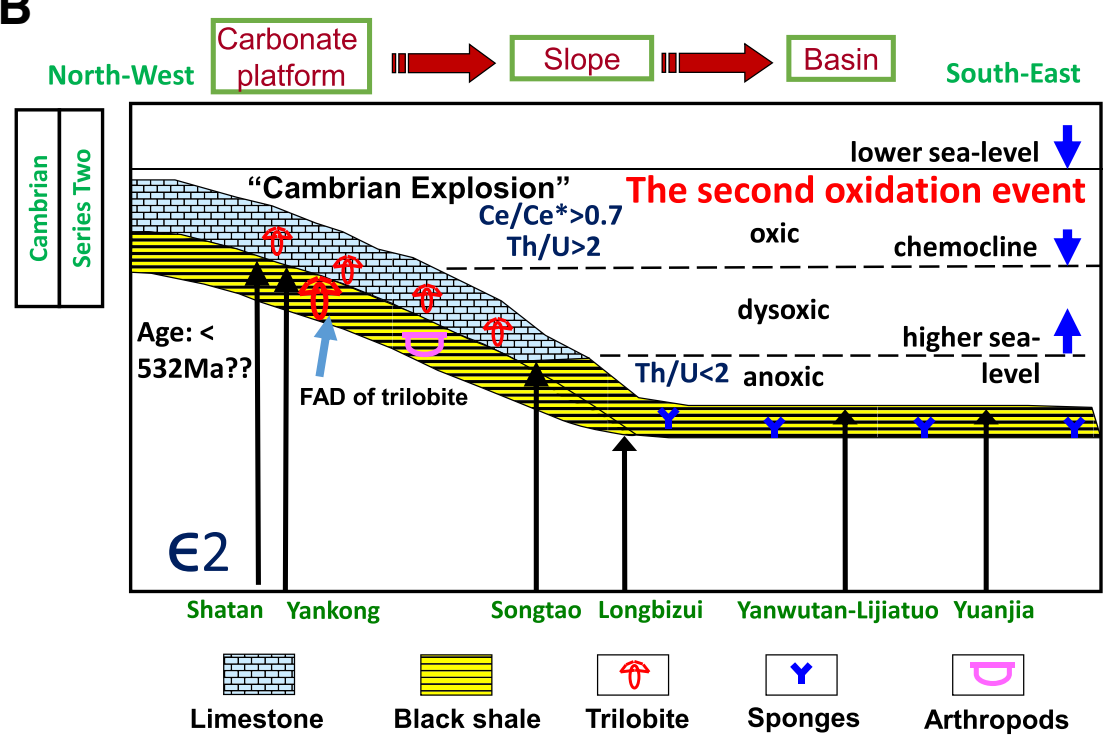

Fig. 13. Environmental evolution from Series one (Fig. 13A) to Series two (Fig.13B) in the Lower Cambrian of the Yangtze Platform. 
2007). In contrast, average $V$ and Mo contents in bulk rock samples are respectively $3357.92 \mathrm{ppm}$ and $57.01 \mathrm{ppm}$, which are much higher than those in Black Sea sediments and kerogen, suggesting that the euxinic conditions may have played a key role in metal enrichment at the beginning of the Early Cambrian.

Black rocks in the Early Cambrian usually contain a Ni-Mo-PGE layer (Fig. 12) strongly enriched in heavy metals, such as $\mathrm{Ni}$ and Mo, with concentrations up to more than ten thousand ppm (Guo et al., 2007a, 2007b; Pi et al., 2013).

This study shows that the Ni-Mo-PGE rich layer was formed under euxinic conditions (Fig. 13), which led to the generation of abundant authigenic sulfide minerals. It is also supported by Mo isotopic compositions (Lehmann et al., 2007). However, the V contents in this layer are extremely high (up to $16,982 \mathrm{ppm}$; Table 2), with values around one hundred times higher than that of the sediments of the Black Sea (Calvert and Pedersen, 1993). Euxinic conditions in bottom water alone cannot cause metal enrichments of this magnitude. Jiang et al. (2006) inferred that the metals were partly derived from marine deposits, organic matter, as well as from hydrothermal input. Some metal contents in kerogen are similar to Black Sea sediments, but much lower than those in bulk rocks, which indicates that multi-metal enrichments in Lower Early Cambrian black rocks were derived from normal sedimentation under anoxic conditions. However, hydrothermal plumes from spreading ridge volcanism may have been the initial source of much of the silica and metals.

We conclude that the deposition of the Ni-Mo polymetallic layer is the result of hydrothermal input, oxygenation, and subsequent changes of the paleoenvironmental conditions in the oceans of the Early Cambrian.

\section{Conclusions}

New high-resolution trace element and REE profiles across the Ediacaran-Cambrian transition on the Yangtze Platform, South China, display clear stratigraphic variations.

1) Trace element concentrations in kerogen and the correlations between $\mathrm{V} / \mathrm{Al}, \mathrm{U} / \mathrm{Al}, \mathrm{Mo} / \mathrm{Al}$ ratios and TOC concentrations in bulk rock show that the sedimentary environment of the lower part of the Niutitang Formation (or Xiaoyanxi Formation) was characterized by euxinic or slightly euxinic conditions, which changed to anoxic conditions. Two oxidation events occurred: firstly in the upper part of the Meishucunian stage, and secondly in the early Qiongzhusian stage. After the first oxidation event, a Ni-Mo-PGE layer was formed under euxinic conditions. The second oxidation event led to oxicsuboxic conditions in shallow water and nearly anoxic conditions in the deep sea, which can be observed in the different facies of the Yangtze Platform.

2) REE patterns in kerogen are similar to modern seawater, probably revealing a sea-level fall and subsequently increasing dissolved oxygen concentrations in the seawater of the Early Cambrian. Consequently, this large-scale oxidation event could have fostered the "Cambrian Explosion" of marine life.

3) Black shale shows enrichments in metals, which could be derived from organic matter in anoxic environments or from authigenic sulfides formed under euxinic conditions, whereas the sources of the metals in the Ni-Mo-PGE layer could be a consequence of hydrothermal activity.

Supplementary data to this article can be found online at http://dx. doi.org/10.1016/j.gr.2016.03.012.

\section{Acknowledgments}

Thanks are expressed for assistance and expertise in the field as well as stimulating discussions with Prof. Dr. Harald Strauss, Prof. Dr. Maoyan Zhu, Prof. Dr. Alan Jay Kaufman, Prof. Yanan Shen, Prof. Dr. Graham A. Shields-Zhou, Dr. Marc Peters, Dr. Peter Chukwunonso Okoli. GQ acknowledges financial support by 973 Program (Nr.2013CB835004), Key Laboratory of Marine Mineral Resources, Ministry of Land and Resources (No. KLMMR-2015-A-03) and the National Natural Science Foundation of China (NSFC Nos. 41173008 and 41473018), which is a contribution to the Sino-German research group FOR 736 funded by the German Science Foundation (FR 557/22-1 and HI 1553/1-2) to G. Franz and D. Hippler.

\section{References}

Algeo, T.J., Maynard, J.B., 2004. Trace-element behavior and redox facies in core shales of Upper Pennsylvanian Kansas-type cyclothems. Chemical Geology 206, 289-318.

Bau, M., Koschinsky, A., Dulski, P., Hein, J.R., 1996. Comparison of the partitioning behaviours of yttrium, rare earth elements, and titanium between hydrogenetic marine ferromanganese crusts and seawater. Geochimica et Cosmochimica Acta 60, 1709-1725.

Bau, M., Dulski, P., 1996. Distribution of yttrium and rare-earth elements in the Penge and Kuruman Iron-Formations, Transvaal Supergroup South Africa. Precambrian Research 79, 37-55.

Calvert, S.E., Pedersen, T.F., 1993. Geochemistry of Recent oxic and anoxic marine sediments: implications for the geological record. Marine Geology 113, 67-88.

Dulski, P., 1994. Interferences of oxide, hydroxide and chloride analyte species in the determination of rare earth elements in geological samples by inductively coupled plasma-mass spectrometry. Fresenius' Journal of Analytical Chemistry 350, 194-203.

Elderfield, H., Greaves, M.J., 1982. The rare earth elements in seawater. Nature 296, 214-219.

Felitsyn, S.B., Vidal, G., Moczydlowska, M., 1998. Trace elements and Sr and C isotopic signatures in late Neoproterozoic and earliest Cambrian sedimentary organic matter from siliciclastic successions in the East European Platform. Geological Magazine $135,537-551$.

Feng, L.J., Li, C., Huang, J., Chang, H.J., Chu, X.L., 2014. A sulfate control on marine middepth euxinia on the early Cambrian (ca. 529-521 Ma) Yangtze platform, South China. Precambrian Research 246, 123-133.

Fu, J.M., Qing, K.Z., 1995. The Geochemistry of Kerogen. Guangdong science and technology press, Guangzhou, pp. 1-78.

Gao, J.F., Lu, J.J., Lai, M.Y., Lin, L.P., Pu, W., 2003. Analysis of trace elements in rock samples using HR-ICPMS. Journal of Nanjing University (Natural Sciences) 39 (6), $844-850$

German, C.R., Holliday, B.P., Elderfield, H., 1991. Redox cycling of rare-earth elements in the suboxic zone of the Black-Sea. Geochimica et Cosmochimica Acta 55, 3553-3558.

Goldberg, T., Strauss, H., Guo, O., Liu, C., 2007. Reconstructing marine redox conditions for the Early Cambrian Yangtze Platform: evidence from biogenic sulphur and organic carbon isotopes. Palaeogeography, Palaeoclimatology, Palaeoecology 254, 175-193.

Guo, Q., Strauss, H., Liu, C., Goldberg, T., Zhu, M., Pi, D., Heubeck, C., Vernhet, E., Yang, X., Fu, P., 2007a. Carbon isotopic evolution of the terminal neoproterozoic and early Cambrian: evidence from the Yangtze platform, South China. Palaeogeography Palaeoclimatology Palaeoecology 254, 140-157.

Guo, Q., Shields, G.A., Liu, C., Strauss, H., Zhu, M., Pi, D., Goldberg, T., Yang, X., 2007b. Trace element chemostratigraphy of two Ediacaran-Cambrian successions in South China: implications for organosedimentary metal enrichment and silicification in the early Cambrian. Palaeogeography Palaeoclimatology Palaeoecology 254, 194-216.

Guo, Q., Strauss, H., Zhu, M., Zhang, J., Yang, X., Lu, M., Zhao, F., 2013. High resolution organic carbon isotope stratigraphy from a slope to basinal setting on the Yangtze Platform, South China: Implications for the Ediacaran - Cambrian transition. Precambrian Research 225, 209-217.

Hu, K., Zhai, J.P., Liu, Y.J., Wang, H.N., 1999. A kind of organic carrier of gold in gold bearing formations-kerogen. Chinese Science Bulletin 44 (1), 84-88.

Ishikawa, T., Ueno, Y., Komiya, T., Sawaki, Y., Han, J., Shu, D., Li, Y., Maruyama, S., Yoshida, N., 2008. Carbon isotope chemostratigraphy of a Precambrian/ Cambrian boundary section in the Three Gorge area South China: prominent global-scale isotope excursions just before the Cambrian explosion. Gondwana Research 14, 193-208.

Ishikawaa, T., Ueno, Y., Shu, D., Li, Y., Han, J., Guo, J., Yoshidab, N., Komiyab, T., 2013. Irreversible change of the oceanic carbon cycle in the earliest Cambrian: high-resolution organic and inorganic carbon chemostratigraphy in the Three Gorges area, South China. Precambrian Research 225, 190-208.

Jiang, S.Y., Chen, Y.Q., Ling, H.F., Yang, J.H., Feng, H.Z., Ni, P., 2006. Trace- and rare-earth element geochemistry and $\mathrm{Pb}-\mathrm{Pb}$ dating of black shales and intercalated $\mathrm{Ni}-\mathrm{Mo}-$ PGE-Au sulfide ores in Lower Cambrian strata, Yangtze Platform, South China. Mineralium Deposita 41 (5), 453-467.

Jiang, S.Y., Yang, J.H., Ling, H.F., Chen, Y.Q., Feng, H.Z., Zhao, K.D., Ni, P., 2007. Extreme enrichment of polymetallic Ni-Mo-PGE-Au in lower Cambrian black shales of South China: an Os isotope and PGE geochemical investigation. Palaeogeography Palaeoclimatology Palaeoecology 254, 217-228.

Kimura, H., Watanabe, Y., 2001. Ocean anoxia at the Precambrian-Cambrian boundary. Geology 29, 995-998. 
Komiya, T., Hirata, T., Kitajima, K., Yamamoto, S., Shibuya, T., Sawaki, Y., Ishikawa, T., Shu, D., Li, Y., Han, J., 2008. Evolution of the composition of seawater through geologic time. Gondwana Research 14, 159-174.

Knoll, A.H., Carroll, S.B., 1999. Early animal evolution: emerging views from comparative biology and geology. Science 284, 2129-2137.

Lehmann, B., Nägler, T.F., Holland, H.D., Wille, M., Mao, J., Pan, J., Dulski, P., 2007. Highly metalliferous carbonaceous shale and early Cambrian seawater. Geology 35, 403-406.

Lewis, B.L., Landing, W.M., 1991. The biogeochemistry of manganese and iron in the Black-Sea. Deep Sea Research 38, S773-S803.

Ling, H.F., Chen, X., Li, D., Wang, D., Shields, Z.G., Zhu, M., 2013. Cerium anomaly variations in Ediacaran-earliest Cambrian carbonates from the Yangtze Gorges area, South China: Implications for oxygenation of coeval shallow seawater. Precambrian Research $225,110-127$.

Luther III, G.W., Church, T.M., Powell, D., 1991. Sulfur speciation and sulfide oxidation in the water column of the Black-Sea. Deep Sea Research 38, S1121-S1137.

Maloof, A.C., Ramezani, J., Bowring, S.A., Fike, D.A., Porter, S.M., Mazouad, M., 2010. Constraints on early Cambrian carbon cycling from the duration of the Nemakit Daldynian-Tommotian boundary $\delta^{13} \mathrm{C}$ shift. Morocco. Geology 38, 623-626.

Marshall, C.R., 2006. Explaining the Cambrian "Explosion" of animals. Annual Review of Earth and Planetary Science 34, 355-384.

McKirdy, D.M., Hall, P.A., Nedin, C., Halverson, G.P., Michaelsen, B.H., Jago, J.B., Gehling J.G., Jenkins, R.J.F., 2011. Paleoredox status and thermal alteration of the lower Cambrian (Series 2) Emu Bay Shale Lagerstätte, South Australia. Australian Journal of Earth Sciences 58, 259-272.

Mclennan, S.M., 2001. Relationships between the trace element composition of sedimentary rocks and upper continental crust. Geochemistry, Geophysics, Geosystems 2, 2000GC000109.

Mossman, D.J., Goodarzi, F., Gentzis, T., 1993. Characterization of insoluble organic matter from the Lower Proterozoic Huronian Supergroup, Elliot Lake, Ontario. Precambrian Research 61, 279-293.

Och, L.M., et al., 2013. Redox changes in Early Cambrian black shales at Xiaotan section, Yunnan Province, South China. Precambrian Research 225, 166-189.

Och, L.M., Cremonese, L., Shields-Zhou, G.A., Poulton, S.W., Struck, U., Ling, H.F., Li, D., Chen, X., Manning, C., Thirlwall, M., Strauss, H., Zhu, M.Y., 2015. Palaeoceanographic controls on spatial redox distribution over the Yangtze Platform during the Ediacaran-Cambrian transition. Sedimentology. http://dx.doi.org/10.1111/sed.12220.

Pan, J., Ma, D., Cao, S., 2004. Trace element geochemistry of the Lower Cambrian black rock series from northwestern Hunan, South China. Progress in Natural Science 14 (1), 64-70.

Pi, D., Liu, C.Q., Deng, H.L., Shields, G., 2008. REE geochemistry of organic matter from black shales of the niutitang formation, Zunyi, Guizhou Province. Acta Mineralogica Sinica 28 (3), 303-310.

Pi, D., Liu, C., Shields-Zhou, G.A., Jiang, S., 2013. Trace and rare earth element geochemistry of black shale and kerogen in the early Cambrian Niutitang Formation in Guizhou province, South China. Precambrian Research 225, 218-229.

Powell, W.G., 2009. Comparison of geochemical and distinctive mineralogical features associated with the Kinzers and Burgess Shale formations and their associated units. Palaeogeography Palaeoclimatology Palaeoecology 277, 127-140.

Powell, W.G., Johnston, P.A., Collum, C.J., 2003. Geochemical evidence for oxygenated bottom waters during deposition of fossiliferous strata of the Burgess Shale Formation. Palaeogeography Palaeoclimatology Palaeoecology 201, 249-268.

Richard, A.K., 1998. Did an ancient deep freeze nearly doom life? Science 281, 5381.

Rimmer, S.M., 2004. Geochemical paleoredox indicators in Devonian-Mississippian black shales, Central Appalachian Basin (USA). Chemical Geology 206, 373-391.

Sawaki, Y., Ohno, T., Fukushi, Y., Komiya, T., Ishikawa, T., Hirata, T., Maruyama, S., 2008. Sr isotope excursion across the Precambrian-Cambrian boundary in the Three Gorges area, South China. Gondwana Research 14, 134-147.

Schröder, S., Grotzinger, J.P., 2007. Evidence for anoxia at Ediacaran-Cambrian boundary: the record of redox sensitive trace elements and rare earth elements in Oman. Journal of the Geological Society of London 164, 175-187.

Shields, G., Stille, P., 2001. Diagenetic constrains on the use of cerium anomalies as palaeoseawater proxies: an isotopic and REE study of Cambrian phosphorites. Chemical Geology 175, 29-48.
Shu, D., 2008. Cambrian explosion: birth of tree of animals. Gondwana Research 14 $219-240$.

Slack, J.F., Grenne, T., Bekker, A., Rouxel, O.J., Lindberg, P.A., 2007. Suboxic deep seawater in the late Paleoproterozoic: evidence from hematitic chert and iron formation related to seafloor-hydrothermal sulfide deposits, central Arizona, USA. Earth and Planetary Science Letters 255, 243-256.

Steiner, M., Wallis, E., Erdtmann, B.D., Zhao, Y., Yang, R., 2001. Submarine-hydrotherma exhalative ore layers in black shales from South China and associated fossils: insights into a Lower Cambrian facies and bio-evolution. Palaeogeography, Palaeoclimatology, Palaeoecology 169, 165-191.

Taylor, S.R., McLennan, S.M., 1985. The Continental Crust: Its Composition and Evolution. Blackwell, London, pp. 57-72.

Tribovillard, N., Algeo, T.J., Lyons, T., Riboulleau, A., 2006. Trace metals as paleoredox and paleoproductivity proxies: an update. Chemical Geology 232, 12-32.

Wang, D., Struck, U., Ling, H.F., Guo, Q.J., Shields-Zhou, G.A., Zhu, M.Y., Yao, S.P., 2015 Marine redox variations and nitrogen cycle of the early Cambrian southern margin of the Yangtze Platform, South China: evidence from nitrogen and organic carbon isotopes. Precambrian Research 267, 209-226.

Wignall, P.B., Twitchett, R.J., 1996. Oceanic anoxia and the end Permian mass extinction. Science 272, 1155-1158.

Wille, M., Nägler, T.F., Lehmann, B., Schröder, S., Kramers, J.D., 2008. Hydrogen sulphide release to surface waters at the Precambrian/Cambrian boundary. Nature 453, 767-769.

Wu, C.D., Chen, Q.Y., Lei, J.J., 1999a. The genesis factors and organic petrology of black shale series from the upper Sinian to the lower Cambrian, southwest of China. Acta Petrologica Sinica 15 (1), 453-461.

Wu, C.D., Yang, C.Y., Chen, Q.Y., 1999b. The origin and geochemical characteristics of Upper Sinian-Lower Cambrian black shales in Western Hunan. Acta Petrologica et Mineralogica 18 (1), 26-39.

Xiao, S., Hu, J., Yuan, X., Parsley, R.L., Cao, R., 2005. Articulated sponges from the Early Cambrian Hetang Formation in southern Anhui, South China: their age and implications for early evolution of sponges. Palaeogeography Palaeoclimatology Palaeoecology 220, 89-117.

Xu, L.G., Lehmann, B., Mao, J.W., 2013. Seawater contribution to polymetallic Ni-MoPGE-Au mineralization in Early Cambrian black shales of South China: evidence from Mo isotope, PGE, trace element, and REE geochemistry. Ore Geology Reviews $52,66-84$.

Yang, A., Zhu, M., Zhang, J., Li, G., 2003. Early Cambrian eodiscoid trilobites of the Yangtze platform and their stratigraphic implications. Progress in Natural Science 13 (11), 861-866.

Yang, J.H., Jiang, S.Y., Ling, H.F., Feng, H.Z., Chen, Y.Q., Chen, J.H., 2004. Paleoceangraphic significance of redox-sensitive metals of black shales in the basal Lower Cambrian Niutitang Formation in Guizhou Province ,South China. Progress in Natural Science 14 (2), 152-157.

Yang, X.L., Zhu, M.Y., Zhao, Y.L., Zhang, J.M., Guo, Q.J., Li, B.X., 2007. Trace Element Geochemical Characteristics from the Ediacaran Cambrian Transition Interval in Eastern Guizhou. South China. Acta Geologica Sinica 81 (10), 1391-1397.

Yang, X.L., Zhu, M.Y., Zhao, Y.L., Zhang, J.M., Guo, Q.J., Pi, D.H., 2008. REE geochemical characteristics of the Ediacaran-Lower Cambrian black rock series in Eastern Guizhou. Geology Review 54 (1), 3-15.

Yarincik, K.M., Murray, R.W., Lyons, T.W., Peterson, L.C., Haug, G.H., 2000. Oxygenation history of bottomwaters in the Cariaco Basin, Venezuela, over the past 578,000 years: results from redox-sensitive metals (Mo, V, Mn, and Fe). Paleoceanography 15 (6), 593-604.

Zhao, F., Caron, J.B., Bottjer, D.J., Hu, S., Yin, Z., Zhu, M., 2014. Diversity and species abundance patterns of the early Cambrian (Series 2, Stage 3) Chengjiang Biota from China. Paleobiology 40 (1), 50-69.

Zhu, M., Zhang, J., Steiner, M., Yang, A., Guoxiang, L., Erdtmann, B.-D., 2003. Sinian and Early Cambrian stratigraphic frameworks from shallow- to deep-water facies of the Yangtze Platform: an integrated approach. Progress in Natural Science 13 (12), 951-960.

Zhu, M., Strauss, H., Shields, G.A., 2007. From snowball earth to the Cambrian bioradiation: calibration of Ediacaran-Cambrian earth history in South China. Palaeogeography Palaeoclimatology Palaeoecology 254, 1-6. 